\title{
Design, synthesis and evaluation of graftable thrombin inhibitors for the preparation of blood-compatible polymer materials
}

\author{
Claudio Salvagnini, ${ }^{a}$ Catherine Michaux, ${ }^{b}$ Julie Remiche, ${ }^{c}$ Johan Wouters, ${ }^{b}$ Paulette Charlier ${ }^{c}$ \\ and Jacqueline Marchand-Brynaert*a \\ a Unité de Chimie Organique et Médicinale, Université catholique de Louvain, Bâtiment \\ Lavoisier, place Louis Pasteur 1, B-1348, Louvain-la-Neuve, Belgium. \\ E-mail: marchand@chim.ucl.ac.be; Fax:+32-10-474168; Tel: +32-10-472740 \\ ${ }^{b}$ Laboratoire de Chimie Biologique Structurale, Facultés Universitaires Notre Dame de la Paix, \\ rue de Bruxelles, B-5000, Namur, Belgium \\ ${ }^{c}$ Laboratoire de Cristallographie des Protéines, Université de Liège, Bâtiment B5, Allée de la \\ chimie, B-4000, Sart-Tilman, Liège, Belgium
}

Received 20th July 2005, Accepted 3rd October 2005

First published as an Advance Article on the web 19th October 2005

Piperazinyl-amide derivatives of $N$ - $\alpha$-(3-trifluoromethyl-benzenesulfonyl)-L-arginine (1) were synthesized as graftable thrombin inhibitors. The possible disturbance of biological activity due to a variable spacer-arm fixed on the $N-4$ piperazinyl position was evaluated in vitro, against human $\alpha$-thrombin, and in blood coagulation assay. Molecular modelling (in silico analysis) and X-ray diffraction studies of thrombin-inhibitor complexes were also performed. The fixation of bioactive molecules on poly(butylene terephthalate) (PBT) and poly(ethylene terephthalate) (PET) membranes was performed by wet chemistry treatment and evaluated by XPS analysis. Surface grafting of inhibitor 1d improved the membrane hemocompatibility by reducing blood clot formation on the modified surface.

\section{Introduction}

The design of biomaterials endowed with high blood compatibility (i.e. preventing clot formation) represents a substantial challenge. ${ }^{1}$ The usual strategies to improve hemocompatibility of material devices consist of selective surface treatments like the grafting of zwitterionic components as biomembrane mimics, ${ }^{2}$ coating with heparin ${ }^{3}$ or thrombomodulin, ${ }^{4}$ two natural anticoagulants, and the immobilization of extracellular matrix proteins or active small peptides for promoting the growth of endothelial cells. ${ }^{5}$ Another approach, less exploited till now, makes use of synthetic drugs that are active in preventing blood clotting. For instance, a thrombin inhibitor derived from Argatroban (MD-805) ${ }^{6}$ was graft-polymerized on the surface of polyurethane membranes. ${ }^{7,8}$ A $p$-amino-benzamidine derivative was covalently immobilized on maleic anhydride copolymer thin films by nucleophilic substitution via a spacer. ${ }^{9}$

In our laboratory, we are interested in the biocompatibilization of polymer materials by their surface derivatization with biologically active molecules of synthetic origin, designed on the basis of medicinal chemistry data. Polyesters, such as poly(ethylene terephthalate) (PET) and poly(butylene terephthalate) (PBT) were chosen as model substrates. For instance, the surface grafting of peptidomimetics of the Arg-Gly-Asp sequence on PET membranes resulted in materials showing interesting cell adhesion properties. ${ }^{10,11}$ Now, we consider the possibility to improve the blood compatibility of polyesters by the covalent grafting of thrombin inhibitors. For that purpose, we have synthesized and evaluated a novel family of thrombin inhibitors equipped with a spacer arm for polymer surface anchorage. This study reports on the design, preparation, surface grafting and in vitro evaluation of the inhibitory activity and anticoagulant effect of this family of compounds based on the L-arginine template. Taking into account possible disturbance due to the spacer arm, in silico evaluation of the interaction with the protein active site has been performed, as well as the $\mathrm{X}$-ray diffraction study of one representative thrombin-inhibitor complex.

\section{Results}

\subsection{Design of the thrombin inhibitors}

Clot formation results from a complex sequence of biochemical events including the blood coagulation cascade in which thrombin plays a central role. Thrombin is a serine protease involved in the conversion of soluble fibrinogen into insoluble fibrin and in the activation of platelet aggregation. ${ }^{12}$ This key protein has become the principal target in the discovery of novel antithrombotic agents. ${ }^{13,14}$ Historically, two research lines have been developed in parallel: (i) the steric inhibitors (non-covalently bound) based on two simple lead compounds, namely $N$-tosylL-arginine methyl ester (TAME, Fig. 1), ${ }^{15}$ and benzamidine, ${ }^{16}$ (ii) the electrophilic inhibitors (covalently bound) derived from the tripeptide motif (D)-Phe-Pro-Arg, ${ }^{17}$ with the peptide arginal Efegatran ${ }^{18}$ and the chloromethylene ketone PPACK, ${ }^{19}$ as leads. The only two synthetic thrombin inhibitors, Argatroban ${ }^{20}$ and Ximelagatran, ${ }^{21}$ available at the moment in the market for the treatment of coagulation complications were developed from the first class of inhibitors.

In our context of biomaterials, the surface bound inhibitor is not allowed to be processed by the enzyme. We thus selected one representative of the first class as a model compound. We considered a simplified structure of Argatroban 1 (Fig. 1) featuring the following characteristics: (i) the guanidyl function of the L-arginine skeleton, for specific ionic interaction with Asp189 in the S1 enzyme pocket - since oral bioavailability ${ }^{14}$ is not a relevant problem in the field of hemocompatible materials, this strongly basic function could be maintained as a recognizing function; (ii) the lipophilic sulfonamide moiety, for interaction with the S2-S3 binding sites - this substituent was also used to introduce a trifluoromethyl group as a useful spectroscopic $\operatorname{tag}^{22}$ for XPS (X-ray photoelectron spectroscopy) analysis of the biomaterial surface and quantification of the amount of grafted inhibitor; (iii) the piperidinyl amide moiety $\left(\mathrm{X}=\mathrm{CH}_{2}\right)$, stable towards processing by the active serine of thrombin and blood esterases - it has been proven that the acid function placed on the piperidine ring of Argatroban is not absolutely necessary for 

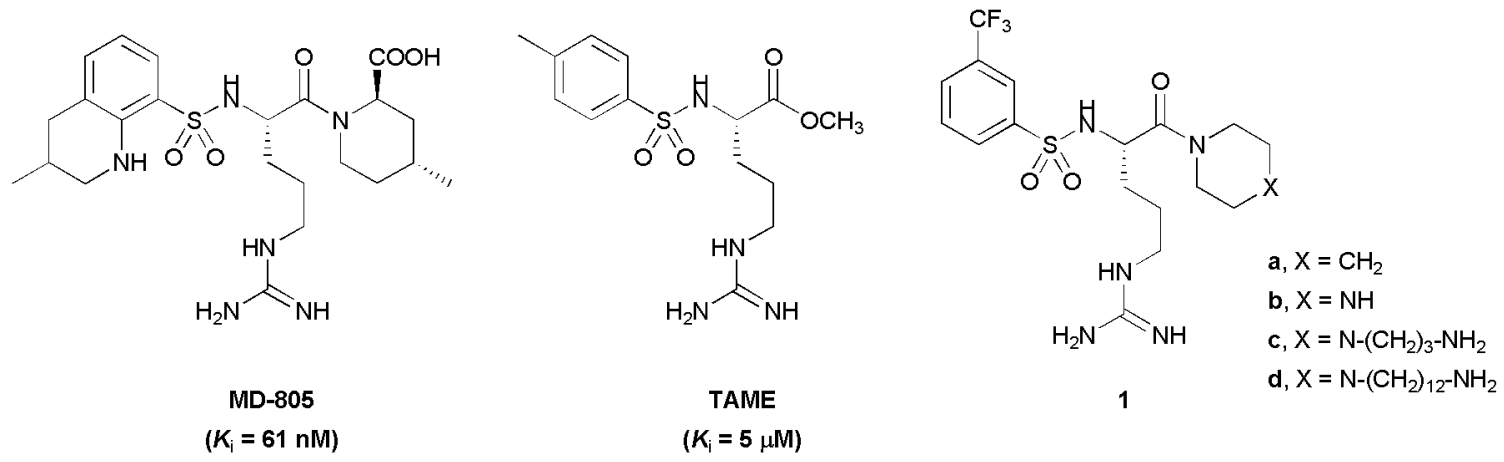

Fig. 1 Thrombin inhibitors.

activity. ${ }^{14}$ Moreover, by removing the carboxylic acid and methyl group in the piperidine ring of Artagroban, we also avoided the control of two chiral centers.

We further transformed the piperidine ring into a piperazine $(\mathrm{X}=\mathrm{NH})$ with the view to introduce a versatile anchorage point for different spacer arms, without creating a new chiral center. Thus, we chose to fix the spacer arm on the amide substituent; this was also the strategy selected by Ito and Imanishi ${ }^{23}$ who transformed the acid function of Argatroban into a polymerizable acrylamide residue.

The effect of the piperazine motif on the activity, and the effect of the spacer arm on the positioning in the enzyme cavity, had to be controlled before using molecules $\mathbf{1}$ in our biomaterial application. Accordingly, we prepared the reference compound 1a, the parent compound $\mathbf{1 b}$, and two derivatives 1c, and 1d, bearing respectively a short and a long spacer. The terminal function of the spacer is a primary amine for coupling to polymers displaying activated hydroxyl or carboxyl functions, following previously established protocols. ${ }^{22,24}$

\subsection{Chemistry}

The target molecules $\mathbf{1}$ were constructed from protected arginine $2(N-\alpha$-Boc- $N$ - $\omega$-nitro-L-arginine) in five steps outlined in Scheme 1. After activation of the carboxyl function, piperidine $\left(\mathrm{X}=\mathrm{CH}_{2}\right), N$-(benzyloxycarbonyl)piperazine $\left(\mathrm{X}=\mathrm{NCO}_{2} \mathrm{Bn}\right)$ and piperazines 8 and $\mathbf{1 3}\left(\mathrm{X}=\mathrm{N}-\right.$ spacer- $\left.-\mathrm{NH}-\mathrm{CO}_{2} \mathrm{PNB}\right)$ were coupled to give the corresponding amides $\mathbf{3 a - d}$ (Table 1). After deprotection of the tert-butoxycarbonyl group (Boc), reaction of the free amine 4 with $m$-(trifluoromethyl)benzenesulfonyl chloride led to compounds 5a-d (Table 1). The final compounds 1a-d (Table 1) were isolated as acetate salts after cleavage of the protective groups by catalytic hydrogenation.

Piperazines 8 and 13 equipped with the protected aminopropyl and aminododecyl spacers were independently prepared according to Scheme 2, by using classical chemistry. The piperazine carrying the $\mathrm{C} 3$ spacer was prepared from 3bromopropylamine by first protecting the amino group, then substitution of the bromine with Boc-piperazine, and finally Boc deprotection. For the preparation of the piperazine carrying the $\mathrm{C} 12$ spacer, the sequence starting from 12-aminododecanoic

Table 1 Yields of inhibitors and intermediates

\begin{tabular}{lllll}
\hline $\mathrm{X}^{a}$ & $\mathbf{3},(\%)$ & $\mathbf{4},(\%)$ & $\mathbf{5},(\%)$ & $\mathbf{1 ,}(\%)$ \\
\hline $\mathrm{CH}_{2}$ & a, 70 & a, quant. & a, 70 & a, 95 \\
$\mathrm{~N}-\mathrm{CO}_{2} \mathrm{Bn}$ & $\mathbf{b}, 63$ & b, quant. & $\mathbf{b}, 70$ & - \\
$\mathrm{N}-\mathrm{H}$ & - & - & - & $\mathbf{b}, 90$ \\
$\mathrm{~N}-\left(\mathrm{CH}_{2}\right)_{3}-\mathrm{NH}-\mathrm{CO}_{2}-\mathrm{PNB}$ & $\mathbf{c}, 60$ & $\mathbf{c}$, quant. & $\mathbf{c}, 75$ & - \\
$\mathrm{N}-\left(\mathrm{CH}_{2}\right)_{3}-\mathrm{NH}_{2}$ & - & - & - & $\mathbf{c}, 90$ \\
$\mathrm{~N}-\left(\mathrm{CH}_{2}\right)_{12}-\mathrm{NH}_{-}-\mathrm{CO}_{2}-\mathrm{PNB}$ & $\mathbf{d}, 65$ & $\mathbf{d}$, quant. & $\mathbf{d}, 75$ & - \\
$\mathrm{N}-\left(\mathrm{CH}_{2}\right)_{12}-\mathrm{NH}_{2}$ & - & - & - & d, 90
\end{tabular}

${ }^{a} \mathrm{Bn}=\mathrm{CH}_{2} \mathrm{Ph} ; \mathrm{PNB}=\mathrm{CH}_{2}-\mathrm{Ph}-p-\mathrm{NO}_{2}$.<smiles>CC(C)(C)OC(=O)N[C@@H](CCCNC(N)=N[N+](=O)[O-])C(=O)O</smiles><smiles></smiles>

$i i i, i v$<smiles>[X]CCN(C(=O)[C@H](CCCNC(=N)N)NS(=O)(=O)c1cccc(C(F)(F)F)c1)C(=O)[C@H](CCCNC(N)=N[N+](=O)[O-])NS(=O)(=O)c1cccc(C(F)(F)F)c1</smiles>

Scheme 1 General synthesis of compounds 1a-d: (i) $\mathrm{iBuO}_{2} \mathrm{CCl}, \mathrm{Et}_{3} \mathrm{~N}$, THF, $-20^{\circ} \mathrm{C}, 15 \mathrm{~min}$; (ii) azacyclohexane, THF, $-20{ }^{\circ} \mathrm{C}$ to $20^{\circ} \mathrm{C}, 1 \mathrm{~h}$; (iii) TFA- $\mathrm{CH}_{2} \mathrm{Cl}_{2} 1: 1,20^{\circ} \mathrm{C}, 2 \mathrm{~h}$; (iv) 3-trifluoromethyl-benzenesulfonyl chloride, $\mathrm{Et}_{3} \mathrm{~N}, \mathrm{CH}_{2} \mathrm{Cl}_{2}, 0^{\circ} \mathrm{C}$ to $20^{\circ} \mathrm{C}, 4 \mathrm{~h} ;(v) \mathrm{H}_{2}, \mathrm{Pd} / \mathrm{C}, \mathrm{EtOH}-\mathrm{AcOH}$ (3:1), $50^{\circ} \mathrm{C}, 12 \mathrm{~h}$.

acid involved the protection of the amino group, the reduction of the carboxylic acid to the corresponding alcohol, and its activation for the substitution with Boc-piperazine.

Intermediates and final products of Schemes 1 and 2 were fully characterized by IR, NMR and Mass spectroscopy (see Experimental).

\subsection{Biological activity}

The inhibition of human thrombin $\left(K_{\mathrm{i}}\right)$ by compounds 1ad was measured spectrophotometrically using as a competitor the chromogenic substrate H-D-phenylalanyl-L-pipecolyl-Larginine- $p$-nitroanilide dihydrochloride (S-2238). The thrombin activity was evaluated from the hydrolysis rate of S-2238 measured at $405 \mathrm{~nm}$ (production of $p$-nitroaniline). All the compounds were active at the micromolar level, similarly to TAME (Table 2). The presence of a basic function on the amide substituent, and the use of this function to fix an amino-alkyl chain, did not significantly modify the activity.

The effect of compounds 1a-d on clot formation on polymer materials surface was also evaluated with human whole blood. Two representative substrates were considered, a cell culture support made of PET and a blood filtration membrane made of 


$$
\text { (c) }
$$

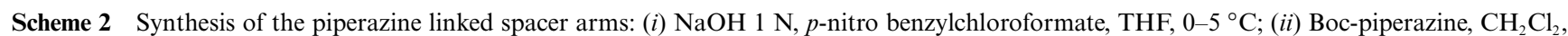
DIPEA, $60^{\circ} \mathrm{C}$; (iii) $\mathrm{HCl} 1 \mathrm{~N}, \mathrm{HOAc}$; (iv) $\mathrm{BH}_{3} \cdot \mathrm{THF}, \mathrm{MeOH}, \mathrm{HCl}$; (v) $\mathrm{MeSO}_{2} \mathrm{Cl}$, pyridine, $\mathrm{CH}_{2} \mathrm{Cl}_{2}, 0-5^{\circ} \mathrm{C}$; (vi) NaI, Boc-piperazine, DIPEA, CH ${ }_{3} \mathrm{CN}$, $85^{\circ} \mathrm{C}$; (vii) $\mathrm{TFA}-\mathrm{CH}_{2} \mathrm{Cl}_{2} 1: 1$.

Table 2 Inhibition of human thrombin

\begin{tabular}{ll}
\hline Compound & $K_{\mathrm{i}} / \mu \mathrm{M}^{a}$ \\
\hline 1a & $4-8$ \\
$\mathbf{1 b}$ & $17-24$ \\
$\mathbf{1 c}$ & $8-18$ \\
$\mathbf{1 d}$ & $25-39$ \\
TAME & $5-6$
\end{tabular}

${ }^{a}$ Reported values are the result of two independent measurements.

PBT. The weight of clot was measured on native polymers and on polymers coated with inhibitors, under standardized conditions, using heparin (Hep) as a control (Table 3).

Compounds 1a-d were found to be active anticoagulants in our experimental conditions (about $100 \mathrm{nmol} \mathrm{cm}{ }^{-2}$ of inhibitor on apparent support surface) reducing the weight of clot on both substrates by about $25 \%$, while TAME was similarly active on PBT only.

Table 3 Inhibitor coating effect on blood clot formation

\begin{tabular}{ll}
\hline Sample & Clot weight $/ \mathrm{mg}^{a}$ \\
\hline PET & $27.5 \pm 1.5$ \\
PET Hep & $11.4 \pm 0.5$ \\
PET 1a & $20.1 \pm 1.4$ \\
PET 1c & $19.6 \pm 4.2$ \\
PET 1d & $21.6 \pm 3.0$ \\
PET TAME & $27.0 \pm 2.0$ \\
PBT & $29.9 \pm 1.0$ \\
PBT Hep & $8.0 \pm 3.2$ \\
PBT 1a & $20.5 \pm 1.0$ \\
PBT 1c & $22.0 \pm 3.2$ \\
PBT 1d & $23.8 \pm 1.5$ \\
PBT TAME & $23.0 \pm 3.1$
\end{tabular}

${ }^{a}$ Results are the mean of 3 independent experiments \pm standard deviation.

\subsection{Docking study}

Our purpose was to localize, by molecular modelling, the possible positions of the spacer arm of compounds 1 in the thrombin cavity. Indeed, after grafting on a solid support via the spacer terminus, the inhibitor should still be able to enter and fit in the enzyme active site.

Thrombin is formed by an A chain of 36 amino acids and a B chain of 259 amino acids connected by a disulfur bridge. This enzyme contains the catalytic triad (Asp-102, His-57, Ser195) characteristic of the chymotrypsin family. Moreover, three important binding pockets have been identified: the specific pocket S1 with Asp-189, the hydrophobic proximal pocket S2 (also called P-pocket) and a larger hydrophobic distal pocket S3 (also called D-pocket). ${ }^{25,26}$

In our docking study, the coordinates of the human thrombin crystal structure complexed with Argatroban (1DWC in PDB) were used. ${ }^{27}$ In order to test the two docking algorithms (Autodock ${ }^{28}$ and Gold $^{29}$ ), Argatroban was firstly docked in thrombin. The resulting complexes are in good agreement with the crystal structure (data not shown).

The most active compound of the series, $1 \mathbf{c}$, was then docked using the two methods. To account for amino acids flexibility of the active site, the solutions common to the two programs were then refined with the Discover 3 module. ${ }^{30}$ Only the three water molecules close to the catalytic triad in the crystal complex were considered during the run. The geometry of the ligand was optimized in vacuo using quantum mechanics and particularly the $\mathrm{HF} / 6-31+\mathrm{G}(\mathrm{d}, \mathrm{p})$. method and the $6-31+\mathrm{G}^{* *}$ basis set (Gaussian98 program). ${ }^{31}$ The guanidyl and terminal amine groups of 1c were considered as protonated at physiological $\mathrm{pH}$. The theoretical $\mathrm{p} K_{\mathrm{a}}$ of the piperazine moiety was calculated with the PALLAS program (CompuDrug Chemistry), and gave a value of 7.6 for the alkylamine. That means that about $50 \%$ of the ligand is not protonated. Here, we have considered this form but the conclusions are the same for the protonated state of the piperazine moiety.

Two binding modes, being the two best ranked solutions of both programs, were identified (Fig. 2). In the first mode (A, 


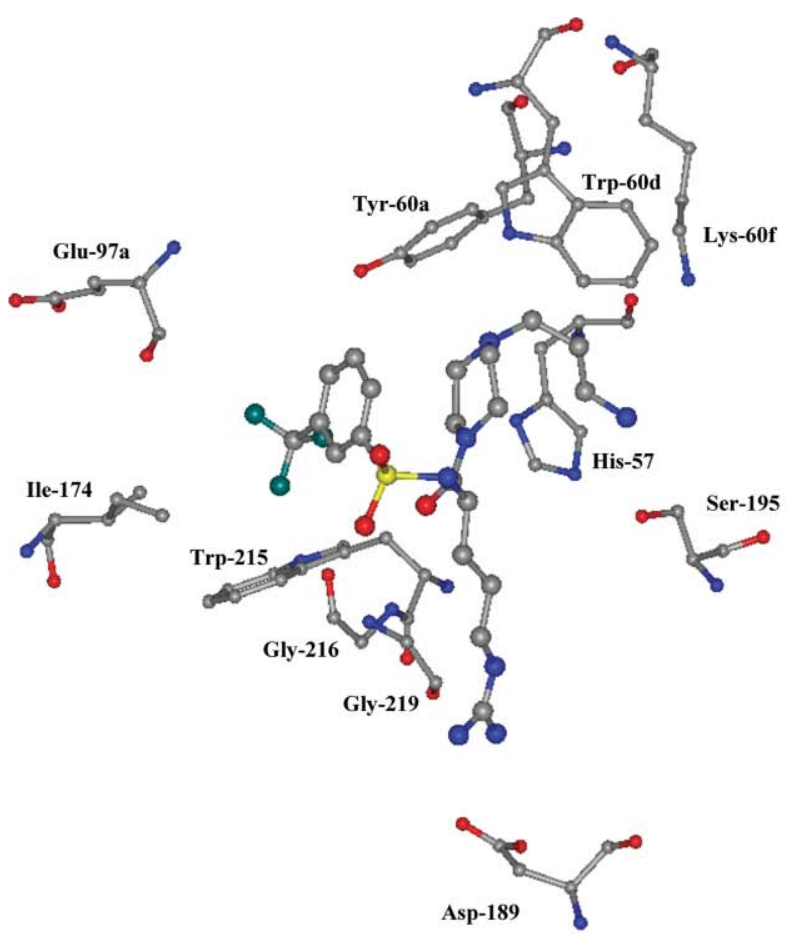

A, "Internal" mode

$-79.2 \mathrm{kcal} \mathrm{mol}^{-1}$

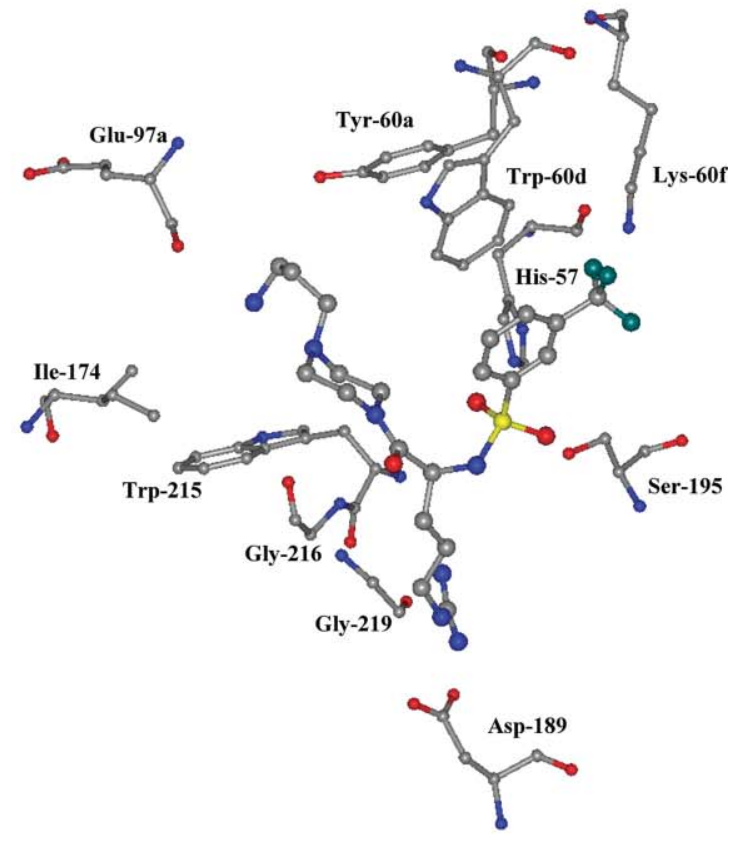

B, "External" mode $-79.6 \mathrm{kcal} \mathrm{mol}^{-1}$

Fig. 2 Two potential binding modes of 1c into the binding site of human thrombin, as deduced by docking and energy minimization studies. Water molecules and hydrogen atoms were omitted for clarity.

"internal"), the spacer points into the binding site of the enzyme, while in the second one (B, "external"), the spacer points toward the surface of the enzyme.

In the "internal" mode, compound 1c approximately lay in the same orientation as Argatroban. The guanidyl function was close to Asp-189 in the S-pocket and interacted by H-bonding with Gly-219 and a water molecule. The lipophilic sulfonamide moiety lay in the D-pocket and the sulfone group interacted with Gly-219. The piperazine group and its spacer arm were buried in the P-pocket where H-bond was observed between Ser-195 and the amine group. The amide carbonyl moiety was also involved in H-bonding with Gly-216.

In the "external" mode, the lipophilic sulfonamide and piperazine moieties were located in the P- and D-pockets respectively. The guanidyl function still lay in the S-pocket. The sulfone group was involved in H-bonding with Ser-195 and His57 , and the amide carbonyl with Gly-219. The trifluoromethyl group interacted with Lys-60f and a water molecule; the protonated amine interacted with Glu-97a and was close to the enzyme surface. Moreover, $\pi-\pi$ stacking interaction was observed between Trp-60d and the phenyl group.

The two complexes were found to be stable and have very close binding energies, -79.2 and $-79.6 \mathrm{kcal} \mathrm{mol}^{-1}$ respectively. Thus, the docking studies clearly showed that both orientations are possible from the energetic point of view.

\subsection{X-Ray diffraction}

Several crystal structures $27,32-36$ of thrombin complexed with covalent and non -covalent inhibitors have been disclosed, since the seminal work of Bode et al. ${ }^{19}$ A single crystal of the novel compound 1c and human $\alpha$-thrombin was prepared by using the hanging drop vapour diffusion technique, in the presence of hirudin peptide fragment; this crystal diffracted to $1.65 \AA$ resolution.

In the X-ray complex structure, a well-defined electron density for the enzyme at the catalytic site and for the inhibitor was found (Fig. 3A). Not surprisingly, the binding mode of compound 1c to the different pockets of the active site of $\alpha$-thrombin was very similar to that of inhibitor MD-805 (Argatroban) as was described in structure $1 \mathrm{DWC}^{27}$ and was close to the "internal mode" described above (see superimposition in Fig. 4). Such experimental observation validates our theoretical approach.

The orientation of compound $\mathbf{1 c}$ in the active site of $\alpha$ thrombin is described in Fig. 3B and the compared distances in inhibitor binding are listed in Table 4. The guanidyl group (N22, $\mathrm{N} 21$ and N19) was oriented to the S-pocket but was unable to form H-bonds with the OD1 and OD2 groups of the Asp-189 side chain, as it is in the $\alpha$-thrombin-Argatroban complex or in the "internal mode". The sulfonamide moiety lay in the Dpocket with the $\mathrm{O} 24$ atom of the sulfone group H-bonded to the amide backbone of Gly-219. The carbonyl O15 and amide $\mathrm{N} 12$ were both $\mathrm{H}$-bonded to the peptidic backbone of Gly216 , as described in the $\alpha$-thrombin-Argatroban complex. In the "internal mode", Gly-216 was slightly shifted. Its carbonyl backbone is moved about $1 \AA$ from its position observed in the $\alpha$ thrombin-Argatroban complex and further from the inhibitor amide N12 atom, resulting in the loss of the hydrogen bond. The loss of one hydrogen bond induced a different positioning of the piperazine cycle, bound in the P-pocket, in comparison with the two X-ray structures where it makes a hydrophobic interaction with the catalytic His-57. The spacer with its amine terminal group (N9) also had a different orientation in the X-ray structure compared to the model. While in the "internal mode" structure we observed H-bonding between the OG hydroxyl function of the active serine and the OE1 and OE2 groups of the Glu-192 side chain, the X-ray structure revealed an unexpected interaction with the NZ terminal amine group of the Lys-60f side chain. Since this spacer does not exist in Argatroban, this kind of interaction was unpredictable by theoretical methods.

\subsection{Inhibitors grafting on surface}

Transformation of hydroxyl group into sulfonic ester is a wellknown process in organic synthesis for alcohol activation towards nucleophilic substitution. This strategy was already successfully 


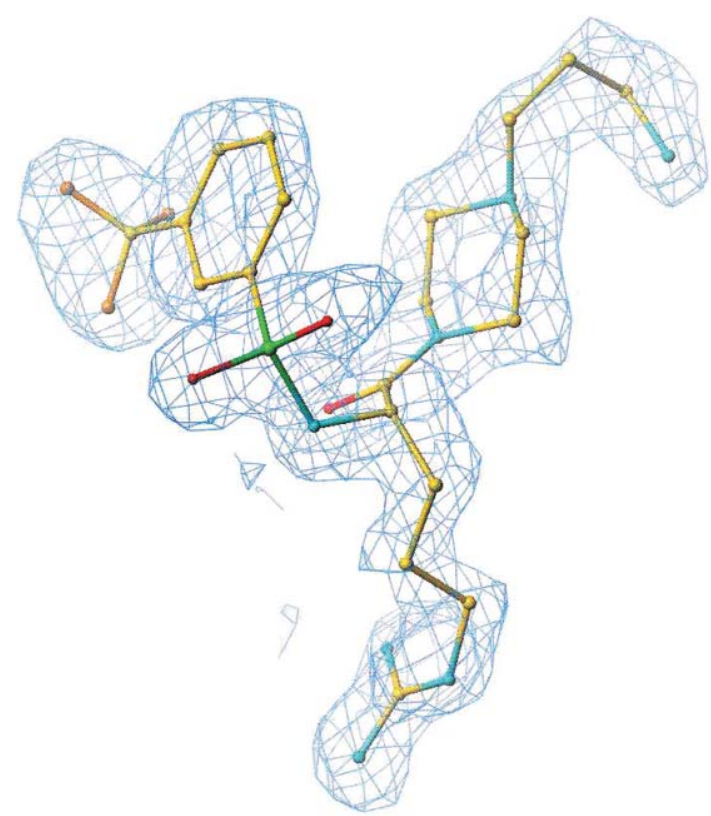

A

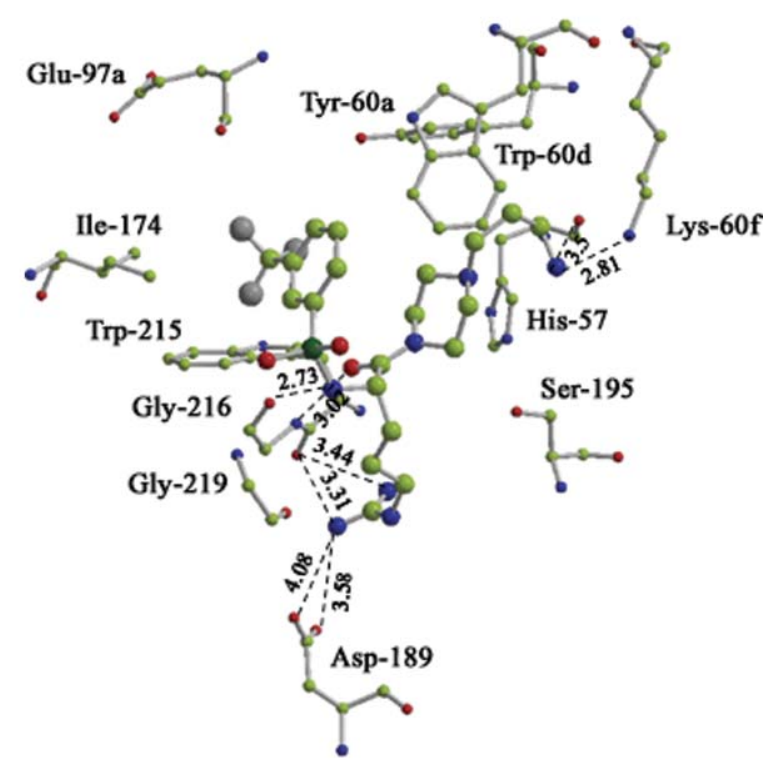

B

Fig. $3\left(2 F_{\mathrm{o}}-F_{\mathrm{c}}\right)$ electron density map of compound $\mathbf{1 c}$, at the active site of the human $\alpha$-thrombin complex, at $1.0 \sigma$ contour level (A). Interactions of compound 1c, at the active site of the human $\alpha$-thrombin complex (B). The inhibitor is in the same orientation as in Fig. 2A. The CPK colour code has been used for both protein and inhibitor atoms, with compound 1c atoms drawn in larger spheres. Shortest contacts with the protein within a distance of less than $4.1 \AA$ are shown with dotted lines.
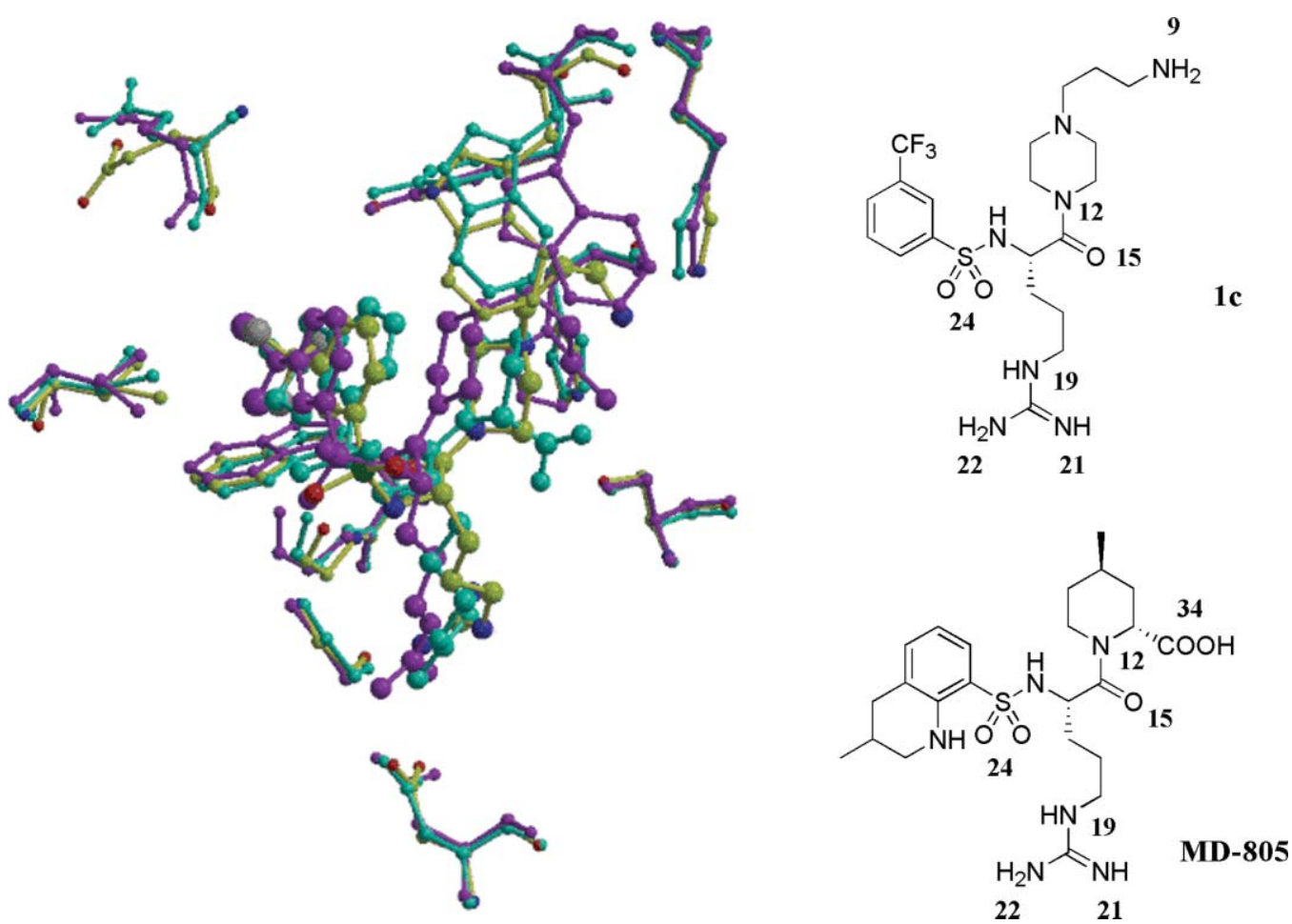

Fig. 4 Superimposed active sites of crystal structure of the $\alpha$-thrombin complex with compound 1c (in CPK color code), the "internal" binding mode model (Fig. 2A) (in magenta) and the crystal structure of the $\alpha$-thrombin complex with compound MD- 805 (Argatroban) from structure $1 \mathrm{DWC}$ (in cyan). Compound $\mathbf{1 c}$ and MD-805 atoms are drawn in larger sphere.

used in our laboratory for polymer functionalization..$^{22}$ Chainend hydroxyl groups of PET and PBT membranes were activated with $p$-toluenesulfonyl chloride ( $\mathrm{TsCl}$ ) and pyridine. The incubation of activated membranes with inhibitor solutions should provide sulfonyl ester displacement and covalent fixation of the active molecules on the surfaces (Scheme 3). The efficiency of the binding was verified by XPS analysis. Blank samples were prepared by processing samples without the activating agent $p$-toluenesulfonyl chloride. The $\mathrm{F}$ detection on blank samples could be attributed to unspecific adsorption. The corrected values of F/C (difference between activated and blank samples) allowed the quantification of grafted inhibitors (Table 5). The fixation of compound 1c on both surfaces was not successful: on PET the difference in F detection on blank and activated samples (act) was not significant, while on PBT no F was detected. On the other hand, compound $\mathbf{1 d}$ resulted in a good level of fixation, with a higher ratio on PET than on PBT. From the F/C corrected values we could determine the concentration of grafted signals in the interface domain analyzed by XPS (50-100 $\AA$ depth or about 10 atomic layers). These values ( $\%$ derivatization) were 
Table 4 Compared distances in inhibitor binding

\begin{tabular}{|c|c|c|c|c|}
\hline & & \multicolumn{3}{|c|}{ Distance/Å } \\
\hline \multicolumn{2}{|c|}{$\begin{array}{l}\text { Inhibitor/protein atom } \\
\text { identification }\end{array}$} & 1DWC & $1 \mathrm{~W} 7 \mathrm{G}$ & Internal mode \\
\hline \multirow[t]{5}{*}{$\mathrm{X}^{a} \mathrm{~N} 22$} & Asp-189 OD1 & 3.05 & 3.58 & 3.33 \\
\hline & Asp-189 OD2 & 2.93 & 4.08 & 2.93 \\
\hline & Ala-190 O & 3.63 & 4.12 & 2.97 \\
\hline & Trp-215 O & 4.06 & 3.31 & 3.80 \\
\hline & Gly-219 O & 4.50 & 4.93 & 2.95 \\
\hline \multirow[t]{5}{*}{$\mathrm{X}^{a} \mathrm{~N} 21$} & Asp-189 OD1 & 5.07 & 5.37 & 4.28 \\
\hline & Asp-189 OD2 & 5.11 & 6.11 & 2.73 \\
\hline & Ala-190 O & 4.36 & 5.19 & 3.97 \\
\hline & Trp-215 O & 3.76 & 3.44 & 4.62 \\
\hline & Gly-219 O & 5.48 & 6.43 & 5.01 \\
\hline $\mathrm{X}^{a} \mathrm{~N} 19$ & Ala-190 O & 3.55 & 3.26 & 3.11 \\
\hline $\mathrm{X}^{a} \mathrm{O} 24$ & Gly-219 N & 3.76 & 3.21 & 3.02 \\
\hline $\mathrm{X}^{a} \mathrm{O} 15$ & Gly-216 N & 3.01 & 3.02 & 3.29 \\
\hline $\mathrm{X}^{a} \mathrm{~N} 12$ & Gly-216 O & 2.85 & 2.73 & 5.05 \\
\hline $\mathrm{X}^{a} \mathrm{O} 34$ & Ser-195 OG & 2.99 & - & - \\
\hline \multirow[t]{5}{*}{$\mathrm{X}^{a} \mathrm{~N} 9$} & Ser-195 OG & - & 5.21 & 2.96 \\
\hline & His-57 O & - & 3.50 & 4.71 \\
\hline & Lys-60f NZ & - & 2.81 & 4.48 \\
\hline & Glu-192 OE1 & - & 6.59 & 2.99 \\
\hline & Glu-192 OE1 & - & 4.80 & 2.63 \\
\hline
\end{tabular}

${ }^{a}$ The inhibitor name is abbreviated by $\mathrm{X}$ and represents compound MD805 (Argatroban) in structure 1DWC and compound 1c (this study) in structure $1 \mathrm{~W} 7 \mathrm{G}$ and "internal mode", respectively. Atom numbers refer to Fig. 4 atom labels.

transformed into pmol $\mathrm{cm}^{-2}$ as previously described for PET. ${ }^{37}$ Indeed this membrane is dense, regular and semi-crystalline.<smiles>[R]NNC(C)(C)OC(=O)c1ccc(C(=O)OCC(C)(C)OC(C)(C)C)cc1</smiles>

Scheme 3 Inhibitors grafting on polyesters surface: (i) TsCl, pyridine, acetone, $20-60{ }^{\circ} \mathrm{C}, 1 \mathrm{~h}$; (ii) $\mathrm{NH}_{2} \mathrm{R}$ (inhibitors), $\mathrm{PBS}$ ( $\left.\mathrm{pH} 7.2\right)-\mathrm{CH}_{3} \mathrm{CN} 1$ : 1,2 h, $20^{\circ} \mathrm{C}$. PET: $n=2$; PBT: $n=4$.
Table 6 Inhibitor grafting effect on blood clot formation

\begin{tabular}{ll}
\hline & Clot weight $/ \mathrm{mg}^{a}$ \\
\hline PET 1d blank & $29.7 \pm 0.4$ \\
PET 1d act & $27.5 \pm 1.5$ \\
PET 1c blank & $31.3 \pm 3.4$ \\
PET 1c act & $31.1 \pm 5.7$ \\
PBT 1d blank & $28.5 \pm 4.1$ \\
PBT 1d act & $21.7 \pm 4.5$ \\
PBT 1c blank & $29.3 \pm 1.4$ \\
PBT 1c act & $29.7 \pm 0.6$
\end{tabular}

${ }^{a}$ Results are the mean of 3 independent experiments \pm standard deviation.

The PBT membrane is tortuous and highly porous; the lack of crystallographic and density data in this case did not allow a similar calculation of surface molecular concentration.

The different morphology of the two polymers may explain the systematically lower fixation ratios observed in the web-like PBT membrane in comparison with the smooth PET membrane. Grafting phenomena occur in the solvent accessible surface of the membrane (open surface) that, in the case of the particular morphology of the considered PBT membrane, may not coincide with the XPS analyzed portion of the sample. Indeed, grafted signals, mostly present in the polymer matrix for instance, could be underestimated by the spectroscopic analysis.

The evaluation of materials hemocompatibility was performed by measuring the weight of clot formed on the supports after static incubation with blood in standardized conditions. The blood clot formation on samples grafted with compound 1d was found to be systematically lower than on blank samples (Table 6). The decrease in blood clot formation was more important on PBT (around 24\%) than on PET (7\%). No effect on blood clot formation was observed on samples treated with compound 1c. This finding was not surprising as low fixation of 1c was detected on PET and no fixation at all was observed on PBT.

\section{Conclusion}

Although significantly less active than Argatroban, the designed inhibitors 1 were found to be sufficiently active for our biomaterial application. The lack of condensed piperidine ring on the N-terminal sulfonyl benzene group, and carboxyl and methyl groups on the C-terminal piperidine ring, in fact caused a weaker inhibition potency. However the activities were found to be similar to amide derivatives of $N$, $\alpha$-substituted-L-arginine precursors of Argatroban ${ }^{15}$ and benzamidine derivatives developed for material hemocompatibilization. ${ }^{9}$

Our novel thrombin inhibitors were designed to be grafted on the surface of biomaterials via a spacer arm, either short (compound 1c) or long (compound 1d). From docking and Xray studies, two potential binding modes of $\mathbf{1 c}$ in thrombin were identified. The docking studies clearly showed that both orientations are possible, from an energetic point of view. Indeed,

Table 5 Atomic surface composition of modified polymers analyzed by XPS

\begin{tabular}{|c|c|c|c|c|c|c|c|c|c|}
\hline & $\mathrm{C} 1 \mathrm{~s}$ & $\mathrm{O} 1 \mathrm{~s}$ & F 1s & $\mathrm{N} 1 \mathrm{~s}$ & Si $2 p$ & $\mathrm{~F} / \mathrm{C}$ & Corr F/C & $\operatorname{Der}^{0} \%^{a}$ & $\mathrm{pmol} \mathrm{cm}^{-2 b}$ \\
\hline PET 1c blank & 72.1 & 27.0 & 0.2 & 0.2 & 0.5 & 0.003 & & & \\
\hline PET 1c act & 73.4 & 25.6 & 0.3 & 0.5 & 0.3 & 0.004 & 0.001 & 0.4 & 11 \\
\hline PET 1d blank & 69.0 & 27.7 & 0.7 & 1.5 & 1.1 & 0.010 & & & \\
\hline PET 1d act & 69.5 & 25.5 & 1.3 & 1.9 & 1.8 & 0.019 & 0.009 & 3.3 & 94 \\
\hline PBT 1c blank & 73.5 & 26.2 & 0.0 & 0.2 & 0.1 & 0 & & & \\
\hline PBT 1c act & 74.5 & 25.2 & 0.0 & 0.2 & 0.1 & 0 & 0 & 0 & 0 \\
\hline PBT 1d blank & 72.1 & 24.2 & 0.2 & 0.8 & 2.8 & 0.003 & & & \\
\hline PBT 1d act & 71.2 & 25.2 & 0.6 & 1.0 & 2.1 & 0.008 & 0.005 & 1.9 & - \\
\hline
\end{tabular}

${ }^{a}$ Percentage of covalently derivatized monomer units. ${ }^{b}$ Concentration of surface fixed inhibitors. 
the two complexes are stable and have very similar binding energies. The second mode, called "external mode", where the molecular spacer is close to the enzyme surface, showed that the grafted inhibitor would still be able to bind the active site of thrombin. Docking studies of analogues of $1 \mathbf{c}$ bearing longer spacers $\left(\left(\mathrm{CH}_{2}\right)_{4}\right.$ and $\left.\left(\mathrm{CH}_{2}\right)_{5}\right)$ were also performed and confirmed the possibility of observing both the A (internal) and B (external) modes of binding (data not shown). Interestingly, for those longer spacers, even in the so-called "internal mode" observed experimentally, the spacer was also able to join the enzyme surface by displacing Trp-60d (data not shown). The same situation should occur with compound 1d bearing a $\left(\mathrm{CH}_{2}\right)_{12}$ spacer arm. Moreover, from biological data, we observed that the substitution of a $\mathrm{CH}_{2}$ group with a $\mathrm{NH}$ function in position 4 of the piperidine ring, as well as the introduction in the same position of a spacer arm, does not change significantly the activity of the inhibitor (Table 1).

All the experimental and theoretical results confirmed our initial hypothesis that an inhibitor carrying a suitable spacer arm in position 4 of the piperazinyl-amide moiety should be able to enter and fit the active site of thrombin providing the specific biological activity that we required for the development of blood-compatible materials. The grafting of our synthetic thrombin inhibitors on a polyester surface was performed and validated by XPS thanks to the incorporation of a fluorine tag into their structures: fixation of compound 1d with a long spacer was more efficient than the grafting of 1c equipped with a short arm. Moreover, due to the morphology of the polymers chosen as models for this study, the ratio of PET surface derivatization was higher than that of PBT.

The grafting of compound 1d on both PET and PBT membranes was found to reduce significantly the blood clot formation. The inhibitor bound on the surface is still active and its surface concentration of about $90 \mathrm{pmol} \mathrm{cm} \mathrm{cm}^{-2}$ seems to be sufficient to inhibit the coagulation cascade. Modification of the grafting protocol and other surface activation techniques are under investigation to increase the surface concentration of bioactive signals and hopefully improve the materials performance. Nevertheless, the proposed technique appeared to be a very promising method for the development of hemocompatible polymer materials, by mild, non-aggressive wet-chemistry treatments.

\section{Experimental}

\subsection{Chemistry}

Reagents and solvents were purchased from Acros Chimica, Aldrich or Fluka. Tetrahydrofuran was dried over sodium/benzophenone, then distilled. Column chromatography was carried out with silica gel 60 (70-230 mesh ASTM) supplied by Merck. The IR spectra were recorded with a Perkin-Elmer 1710 instrument, only the most significant adsorption bands being reported. The mass spectra were obtained with a Finnigan MAT TSQ-70 instrument. The high resolution mass spectra (HRMS) were performed at the University of Mons, Belgium (Professor R. Flammang). The microanalyses were performed at the Christopher Ingold Laboratories of University College, London (Dr A. Stones). The melting points were determined with an Electrothermal microscope and are uncorrected. The ${ }^{1} \mathrm{H}$ and ${ }^{13} \mathrm{C}$ NMR spectra were recorded on Varian Gemini 300 (at $300 \mathrm{MHz}$ for proton and $75 \mathrm{MHz}$ for carbon) or Bruker AM500 spectrometers (at $500 \mathrm{MHz}$ for proton and $125 \mathrm{MHz}$ for carbon); the chemical shifts were reported in ppm $(\delta)$ downfield from tetramethylsilane (TMS).

4.1.1 General procedure for the preparation of 5-(3-nitroguanidino)-2(S)-tert-butoxycarbonylamino-1-(azacyclohexan-1-yl)pentan-1-one (3a-c). $N$ - $\alpha$-Boc- $N$ - $\alpha$-nitro-L-arginine $(1.00 \mathrm{~g}$, $3.13 \mathrm{mmol}, 1$ equiv) was dissolved in dry THF $(10 \mathrm{~mL})$ and $\mathrm{Et}_{3} \mathrm{~N}$ (0.32 g, $3.13 \mathrm{mmol}, 1$ equiv). Isobutyl chloroformate
( $0.43 \mathrm{~g}, 3.13 \mathrm{mmol}, 1$ equiv) was then added dropwise at -20 to $-25^{\circ} \mathrm{C}$. After $30 \mathrm{~min}$ azacyclohexane $(3.13 \mathrm{mmol}, 1$ equiv) in dry THF $(2 \mathrm{~mL})$ was added dropwise at $-20{ }^{\circ} \mathrm{C}$ and stirred for an additional $20 \mathrm{~min}$. The solution was allowed to warm up to room temperature and stirred for $1 \mathrm{~h}$. The solvent was then evaporated and the solid residue partitioned between EtOAc and brine. The organic layer was dried over $\mathrm{MgSO}_{4}$ and concentration under vacuum gave crude 3 that was purified by column chromatography on $\mathrm{SiO}_{2}($ EtOAc) with a yield of about $65 \%$.

5-(3-Nitroguanidino)-2(S)-tert-butoxycarbonylamino-1-(piperidin-1-yl)pentan-1-one (3a). White amorphous solid; $R_{\mathrm{f}}=0.5$ $\left(\mathrm{SiO}_{2}\right.$, EtOAc, UV); IR $v_{\max }\left(\mathrm{CH}_{2} \mathrm{Cl}_{2}\right.$ liquid film on $\left.\mathrm{NaCl}\right) 3292$, $2932,2857,1700,1624,1522,1445,1366,1254,1165 \mathrm{~cm}^{-1} ; \delta_{\mathrm{H}}$ (300 MHz, $\left.\mathrm{CDCl}_{3}, \mathrm{Me}_{4} \mathrm{Si}\right) 1.42(9 \mathrm{H}, \mathrm{s}), 1.56(2 \mathrm{H}, \mathrm{m}), 1.65(6 \mathrm{H}$, $\mathrm{m}), 1.74(2 \mathrm{H}, \mathrm{m}), 3.27(1 \mathrm{H}, \mathrm{m}), 3.36(2 \mathrm{H}, \mathrm{m}), 3.52(1 \mathrm{H}, \mathrm{m})$, $3.59(2 \mathrm{H}, \mathrm{m}), 4.58(1 \mathrm{H}, \mathrm{m}), 5.90(1 \mathrm{H}, \mathrm{d}, J=7.0 \mathrm{~Hz}), 7.87(2 \mathrm{H}$, s), $8.95(1 \mathrm{H}, \mathrm{s}) ; \delta_{\mathrm{C}}\left(50 \mathrm{MHz}, \mathrm{CDCl}_{3}, \mathrm{Me}_{4} \mathrm{Si}\right) 24.2,24.3,25.3$, 26.2, 28.3, 31.3, 40.1, 43.2, 46.4, 48.5, 80.3, 156.6, 159.3, 169.5; MS (ESI) $m / z 387.0\left(\mathbf{M}^{+}, 100 \%\right)$; HRMS (ESI) $m / z: 425.1912$ (calcd for $\mathrm{C}_{16} \mathrm{H}_{30} \mathrm{~N}_{6} \mathrm{O}_{5} \mathrm{~K}=425.1915$ ).

5-(3-Nitroguanidino)-2(S)-tert-butoxycarbonylamino-1-[4-(benzyloxycarbonyl)piperazin-1-yl|pentan-1-one (3b). White amorphous solid; $R_{\mathrm{f}}=0.1\left(\mathrm{SiO}_{2}\right.$, EtOAc, UV); IR $v_{\max }(\mathrm{KBr})$ $3305,2979,2932,1700,1635,1430,1251,1231,1165 \mathrm{~cm}^{-1} ; \delta_{\mathrm{H}}$ $\left(300 \mathrm{MHz}, \mathrm{CDCl}_{3}, \mathrm{Me}_{4} \mathrm{Si}\right) 1.42(9 \mathrm{H}, \mathrm{s}), 1.64(2 \mathrm{H}, \mathrm{m}), 1.72(2 \mathrm{H}$, m), $3.20(1 \mathrm{H}, \mathrm{m}), 3.30-3.60(8 \mathrm{H}, \mathrm{m}), 3.65(1 \mathrm{H}, \mathrm{m}), 4.57(1 \mathrm{H}$, $\mathrm{m}), 5.13(2 \mathrm{H}, \mathrm{s}), 5.80(1 \mathrm{H}, \mathrm{m}), 7.34(5 \mathrm{H}, \mathrm{m}), 7.74(2 \mathrm{H}, \mathrm{m}), 8.87$ $(1 \mathrm{H}, \mathrm{m}) ; \delta_{\mathrm{C}}\left(50 \mathrm{MHz}, \mathrm{CDCl}_{3}, \mathrm{Me}_{4} \mathrm{Si}\right) 24.5,28.3,30.7,40.5$, 41.9, 43.6, 43.7, 45.2, 49.2, 67.5, 80.2, 127.8, 128.1, 128.5, 136.3, $154.9,156.1,159.5,170.5$; MS (APCI) $m / z 522.0\left(\mathrm{M}^{+}, 100 \%\right)$, $465.9(50 \%)$, $422.1(7 \%)$; Anal. calcd. for $\mathrm{C}_{23} \mathrm{H}_{35} \mathrm{~N}_{7} \mathrm{O}_{7} \cdot 0.5 \mathrm{H}_{2} \mathrm{O}$ : C, 52.18; H, 6.63; N, 17.98\%. Found: C, 52.32; H, 6.85; N, $18.04 \%$.

$\{(S)$-1-[4-(3-(4-Nitrobenzyloxycarbonyl)aminopropyl)piperazine-1-carbonyl]-4-nitroguanidino-butyl $\}$ carbamic acid tertbutyl ester (3c). Beige amorphous solid; $R_{\mathrm{f}}=0.1 \quad\left(\mathrm{SiO}_{2}\right.$, isopropanol- $\mathrm{CH}_{2} \mathrm{Cl}_{2} 10$ : 90, UV); IR $v_{\max }\left(\mathrm{CH}_{2} \mathrm{Cl}_{2}\right.$ liquid film on $\mathrm{NaCl}) 3305,2926,2857,1704,1629,1521,1445,1347$, $1254 \mathrm{~cm}^{-1} ; \delta_{\mathrm{H}}\left(500 \mathrm{MHz}, \mathrm{CDCl}_{3}, \mathrm{Me}_{4} \mathrm{Si}\right) 1.43(9 \mathrm{H}, \mathrm{s}), 1.63(2 \mathrm{H}$, $\mathrm{m}), 1.71(4 \mathrm{H}, \mathrm{m}), 2.42(2 \mathrm{H}, \mathrm{m}), 2.46(2 \mathrm{H}, \mathrm{m}), 2.50(2 \mathrm{H}, \mathrm{m})$, $3.25(1 \mathrm{H}, \mathrm{m}), 3.30(2 \mathrm{H}, \mathrm{m}), 3.43(2 \mathrm{H}, \mathrm{m}), 3.61(3 \mathrm{H}, \mathrm{m}), 4.56$ $(1 \mathrm{H}, \mathrm{m}), 5.18(2 \mathrm{H}, \mathrm{s}), 5.58(1 \mathrm{H}, \mathrm{t}, J=5.7 \mathrm{~Hz}), 5.81(1 \mathrm{H}, \mathrm{d}, J=$ $8.3 \mathrm{~Hz}), 7.50(2 \mathrm{H}, \mathrm{d}, J=8.4 \mathrm{~Hz}), 7.59(2 \mathrm{H}, \mathrm{m}), 8.21(2 \mathrm{H}, \mathrm{d}$, $J=8.4 \mathrm{~Hz}), 8.68(1 \mathrm{H}, \mathrm{m}) ; \delta_{\mathrm{C}}\left(75 \mathrm{MHz}, \mathrm{CDCl}_{3}, \mathrm{Me}_{4} \mathrm{Si}\right) 24.2$, 26.0, 28.2, 31.2, 40.1, 42.0, 45.3, 48.6, 52.4, 52.9, 56.1, 64.9, 80.4, 123.6, 128.0, 144.1, 147.4, 155.8, 156.5, 159.3, 169.8; MS (APCI) $m / z 624.2\left(\mathrm{M}^{+}, 100 \%\right)$; Anal. calcd. for $\mathrm{C}_{26} \mathrm{H}_{41} \mathrm{~N}_{9} \mathrm{O}_{9} \cdot \mathrm{H}_{2} \mathrm{O}: \mathrm{C}$, 48.66; H, 6.76; N, 19.65\%. Found: C, 48.62; H, 6.16; N, 19.05\%.

\{12-[4-( $(S)$-2-tert-Butoxycarbonylamino-5-nitroguanidinopentanoyl)piperazin-1-yl|-dodecyl $\}$ carbamic acid 4-nitrobenzyl ester (3d). Yellow amorphous solid; $R_{\mathrm{f}}=0.5\left(\mathrm{SiO}_{2}, \mathrm{EtOAc}\right.$, UV); IR $v_{\max }\left(\mathrm{CH}_{2} \mathrm{Cl}_{2}\right.$ liquid film on $\left.\mathrm{NaCl}\right) 3354,2928,2855$, $1708,1650,1523,1437,1347,1254 \mathrm{~cm}^{-1} ; \delta_{\mathrm{H}}\left(300 \mathrm{MHz}, \mathrm{CDCl}_{3}\right.$, $\left.\mathrm{Me}_{4} \mathrm{Si}\right) 1.26(12 \mathrm{H}, \mathrm{m}), 1.43(9 \mathrm{H}, \mathrm{s}), 1.49(4 \mathrm{H}, \mathrm{m}), 1.64(2 \mathrm{H}, \mathrm{m})$, $1.75(2 \mathrm{H}, \mathrm{m}), 2.36(2 \mathrm{H}, \mathrm{t}, J=7.2 \mathrm{~Hz}), 2.45(4 \mathrm{H}, \mathrm{m}), 3.19(2 \mathrm{H}$, $\mathrm{q}, J=6.6 \mathrm{~Hz}), 3.26(1 \mathrm{H}, \mathrm{m}), 3.46(2 \mathrm{H}, \mathrm{m}), 3.64(3 \mathrm{H}, \mathrm{m}), 4.56$ $(1 \mathrm{H}, \mathrm{m}), 4.85(1 \mathrm{H}, \mathrm{m}), 5.19(2 \mathrm{H}, \mathrm{s}), 5.85(1 \mathrm{H}, \mathrm{d}, J=8.2 \mathrm{~Hz})$, $7.51(2 \mathrm{H}, \mathrm{d}, J=8.7 \mathrm{~Hz}), 7.80(2 \mathrm{H}, \mathrm{m}), 8.21(2 \mathrm{H}, \mathrm{d}, J=8.7$ $\mathrm{Hz}), 8.84(1 \mathrm{H}, \mathrm{m}) ; \delta_{\mathrm{C}}\left(50 \mathrm{MHz}, \mathrm{CDCl}_{3}, \mathrm{Me}_{4} \mathrm{Si}\right) 26.8,27.5,28.0$, 29.3, 29.6, 29.9, 41.2, 43.6, 52.9, 58.7, 65.0, 71.5, 123.6, 128.0, 144.3, 147.6, 155.5, 155.7, 159.8, 168.0; MS (APCI) $\mathrm{m} / z$ 750.3 $\left(\mathrm{M}^{+}, 100 \%\right)$; Anal. calcd. for $\mathrm{C}_{35} \mathrm{H}_{59} \mathrm{~N}_{9} \mathrm{O}_{9} \cdot 0.5 \mathrm{H}_{2} \mathrm{O}: \mathrm{C}, 55.39 ; \mathrm{H}$, 7.97; N, 16.61\%. Found: C, 55.70; H, 8.00; N, 16.14\%.

4.1.2 General procedure for the preparation of 2(S)-amino-5nitroguanidino-1-(azacyclohexan-1-yl)pentan-1-one (4). Product $3(1.25 \mathrm{mmol})$ was dissolved in a $1: 1$ mixture of TFA- $\mathrm{CH}_{2} \mathrm{Cl}_{2}$ 
$(10 \mathrm{~mL})$ and stirred at room temperature for $3 \mathrm{~h}$. The solution was concentrated at reduced pressure and the obtained orange gel was suspended and triturated in $\mathrm{Et}_{2} \mathrm{O}$ until precipitation of the trifluoroacetate salt as a crystalline solid occurred. The precipitate was washed with $\mathrm{Et}_{2} \mathrm{O}$ and used directly in the next reaction (quantitative yield). For spectroscopic analysis the product was converted to the free amine by dissolution in $\mathrm{NaOH}$ $1 \mathrm{~N}$, and extraction of the aqueous solution with EtOAc (about $90 \%$ product recovery).

2(S)-Amino-5-nitroguanidino-1-(piperidin-1-yl)pentan-1-one (4a). White amorphous solid; IR $v_{\max }(\mathrm{KBr}) 3292,2937,2857$, $1617,1439,1257 \mathrm{~cm}^{-1} ; \delta_{\mathrm{H}}\left(300 \mathrm{MHz}, \mathrm{D}_{2} \mathrm{O}\right) 1.47(2 \mathrm{H}, \mathrm{m}), 1.64$ $(6 \mathrm{H}, \mathrm{m}), 1.91(2 \mathrm{H}, \mathrm{m}), 3.29-3.42(4 \mathrm{H}, \mathrm{m}), 3.51(1 \mathrm{H}, \mathrm{m}), 3.67$ $(1 \mathrm{H}, \mathrm{m}), 4.57(1 \mathrm{H}, \mathrm{t}, J=5.7 \mathrm{~Hz}) ; \delta_{\mathrm{C}}\left(50 \mathrm{MHz}, \mathrm{D}_{2} \mathrm{O}\right) 23.9$, 25.2, 25.6, 26.3, 27.5, 30.6, 40.4, 44.4, 47.2, 50.7, 159.1, 167.1; MS (ESI) $m / z 287.1\left(\mathrm{M}^{+}, 100 \%\right.$ ); HRMS (ESI) $m / z: 309.1643$ (calcd for $\mathrm{C}_{11} \mathrm{H}_{22} \mathrm{~N}_{6} \mathrm{O}_{3} \mathrm{Na}=309.1651$ ).

4-(2-(S)-Amino-5-nitroguanidino-pentanoyl)piperazine-1-carboxylic acid benzyl ester (4b). White solid; IR $v_{\max }(\mathrm{KBr}) 3290$, $3055,2938,1700,1638,1430,1265,1232 \mathrm{~cm}^{-1} ; \delta_{\mathrm{H}}(300 \mathrm{MHz}$, $\left.\mathrm{CDCl}_{3}, \mathrm{Me}_{4} \mathrm{Si}\right) 1.47(2 \mathrm{H}, \mathrm{m}), 1.70(4 \mathrm{H}, \mathrm{m}), 3.30(2 \mathrm{H}, \mathrm{m})$, 3.35-3.65 $(8 \mathrm{H}, \mathrm{m}), 3.82(1 \mathrm{H}, \mathrm{m}), 5.15(2 \mathrm{H}, \mathrm{s}), 7.36(5 \mathrm{H}, \mathrm{m})$, $7.80-8.40\left(3 \mathrm{H}\right.$, br); $\delta_{\mathrm{C}}\left(50 \mathrm{MHz}\right.$, acetone, $\left.\mathrm{Me}_{4} \mathrm{Si}\right) 25.1$, 29.1, 41.4, 43.6, 44.7, 44.9, 46.6, 51.9, 68.2, 129.1, 129.2, 129.7, 138.5, 156.2, 161.2, 170.5; MS (APCI) $m / z 422.4\left(\mathrm{M}^{+}, 100 \%\right.$ ); HRMS (ESI) $m / z$ : 422.2172 (calcd for $\mathrm{C}_{18} \mathrm{H}_{28} \mathrm{~N}_{7} \mathrm{O}_{5}=422.2152$ ).

\{3-[4-(2-(S)-Amino-5-nitroguanidino-pentanoyl)piperazin-1yl]propyl carbamic acid 4-nitrobenzyl ester (4c). Brown amorphous solid; IR $v_{\max }(\mathrm{KBr}) 3600-3200,1701,1638,1551$, $1329 \mathrm{~cm}^{-1} ; \delta_{\mathrm{H}}\left(300 \mathrm{MHz}, \mathrm{D}_{2} \mathrm{O}\right) 1.66(2 \mathrm{H}, \mathrm{m}), 1.90(4 \mathrm{H}, \mathrm{m}), 3.00$ $(1 \mathrm{H}, \mathrm{m}), 3.20(5 \mathrm{H}, \mathrm{m}), 3.27(3 \mathrm{H}, \mathrm{m}), 3.59(4 \mathrm{H}, \mathrm{m}), 4.05(1 \mathrm{H}$, $\mathrm{m}), 4.53(1 \mathrm{H}, \mathrm{m}), 5.17(2 \mathrm{H}, \mathrm{s}), 7.53(2 \mathrm{H}, \mathrm{d}, J=8.1 \mathrm{~Hz}), 8.19$ $(2 \mathrm{H}, \mathrm{d}, J=8.1 \mathrm{~Hz}) ; \delta_{\mathrm{C}}\left(75 \mathrm{MHz}, \mathrm{CDCl}_{3}, \mathrm{Me}_{4} \mathrm{Si}\right) 25.1,26.1$, 29.7, 40.3, 40.7, 42.3, 45.2, 50.7, 52.7, 53.3, 56.3, 65.0, 123.6, 128.0, 144.2, 147.4, 155.8, 159.6, 173.2; MS (APCI) $\mathrm{m} / \mathrm{z} 524.2$ $\left(\mathrm{M}^{+}, 100 \%\right)$; Anal. calcd. for $\mathrm{C}_{21} \mathrm{H}_{33} \mathrm{~N}_{9} \mathrm{O}_{7}: \mathrm{C}, 48.18 ; \mathrm{H}, 6.35 ; \mathrm{N}$, $24.08 \%$. Found: C, 48.14; H, 6.43; N, 24.15\%.

\{12-[4-((S)-2-Amino-5-nitroguanidino-pentanoyl)piperazin-1yl|dodecyl\}carbamic acid 4-nitrobenzyl ester (4d). Yellow amorphous solid; IR $v_{\max }\left(\mathrm{CH}_{2} \mathrm{Cl}_{2}\right.$ liquid film on $\left.\mathrm{NaCl}\right) 3300$, $2928,2855,1708,1690,1521,1347,1256 \mathrm{~cm}^{-1} ; \delta_{\mathrm{H}}(300 \mathrm{MHz}$, $\left.\mathrm{D}_{2} \mathrm{O}\right) 1.18(16 \mathrm{H}, \mathrm{m}), 1.20(2 \mathrm{H}, \mathrm{m}), 1.43(2 \mathrm{H}, \mathrm{m}), 1.69(4 \mathrm{H}, \mathrm{m})$, $1.91(2 \mathrm{H}, \mathrm{m}), 3.11(6 \mathrm{H}, \mathrm{m}), 3.29(2 \mathrm{H}, \mathrm{m}), 3.64(4 \mathrm{H}, \mathrm{m}), 4.55$ $(1 \mathrm{H}, \mathrm{m}), 5.17(2 \mathrm{H}, \mathrm{s}), 7.54(2 \mathrm{H}, \mathrm{d}, J=8.1 \mathrm{~Hz}), 8.22(2 \mathrm{H}, \mathrm{d}, J=$ $8.1 \mathrm{~Hz}) ; \delta_{\mathrm{C}}\left(50 \mathrm{MHz}, \mathrm{CDCl}_{3}, \mathrm{Me}_{4} \mathrm{Si}\right) 24.2,24.3,24.4,27.3,27.5$, $40.3,40.8,41.6,43.3,51.2,51.6,51.8,51.9,57.3,57.5,59.3$, $65.1,73.1,124.4,129.0,145.2,146.7,156.8,162.0,168.7$; MS (APCI) $m / z 650.5\left(\mathrm{M}^{+}, 100 \%\right)$; HRMS (ESI): 650.4001 (calcd for $\mathrm{C}_{30} \mathrm{H}_{52} \mathrm{~N}_{9} \mathrm{O}_{7}=650.3990$ ).

4.1.3 General procedure for the preparation of 3-trifluoromethyl-benzenesulfonic acid [4-guanidino-1 $(S)$-(azacyclohexan1-ylcarbonyl)butyl|amide (5). Product $4(0.54 \mathrm{mmol}, 1$ equiv) was dissolved $\mathrm{CH}_{2} \mathrm{Cl}_{2}(5 \mathrm{~mL})$ and $\mathrm{Et}_{3} \mathrm{~N}(0.1688 \mathrm{~g}, 1.67 \mathrm{mmol}$, 3.1 equiv). Then 3-trifluoromethyl-benzenesulfonyl chloride ( 0 . $1527 \mathrm{~g}, 0.64 \mathrm{mmol}, 1.2$ equiv) in $\mathrm{CH}_{2} \mathrm{Cl}_{2}(1 \mathrm{~mL})$ was added dropwise with stirring at $0-5{ }^{\circ} \mathrm{C}$. The solution was stirred for additional $2 \mathrm{~h}$ at room temperature, then the mixture was washed with brine, dried over $\mathrm{MgSO}_{4}$, and evaporated under reduced pressure. The residue was purified by column chromatography on $\mathrm{SiO}_{2}(\mathrm{EtOAc})$ with a yield of about $75 \%$.

3-Trifluoromethyl-benzenesulfonic acid [4-nitroguanidino-1 $(S)$ (piperidin-1-ylcarbonyl)butyl]amide (5a). White amorphous solid; $R_{\mathrm{f}}=0.2\left(\mathrm{SiO}_{2}\right.$, EtOAc, UV); IR $v_{\max }(\mathrm{KBr}) 3228,2942$, $2857,1628,1430,1326,1256,1164,1129 \mathrm{~cm}^{-1} ; \delta_{\mathrm{H}}(300 \mathrm{MHz}$, $\left.\mathrm{CDCl}_{3}, \mathrm{Me}_{4} \mathrm{Si}\right) 1.23(2 \mathrm{H}, \mathrm{m}), 1.51(4 \mathrm{H}, \mathrm{m}), 1.65(2 \mathrm{H}, \mathrm{m}), 1.86$ $(2 \mathrm{H}, \mathrm{m}), 3.16(3 \mathrm{H}, \mathrm{m}), 3.37(3 \mathrm{H}, \mathrm{m}), 4.11(1 \mathrm{H}, \mathrm{m}), 6.53(1 \mathrm{H}$, $\mathrm{m}), 7.61(2 \mathrm{H}, \mathrm{m}), 7.68(1 \mathrm{H}, \mathrm{t}, J=7.5 \mathrm{~Hz}), 7.83(1 \mathrm{H}, \mathrm{d}, J=$
$7.5 \mathrm{~Hz}), 8.06(1 \mathrm{H}, \mathrm{d}), 8.07(1 \mathrm{H}, \mathrm{s}), 8.79(1 \mathrm{H}, \mathrm{m}) ; \delta_{\mathrm{C}}(50 \mathrm{MHz}$, $\left.\mathrm{CDCl}_{3}, \mathrm{Me}_{4} \mathrm{Si}\right)$ 23.9, 24.6, 25.2, 26.2, 30.1, 40.5, 43.5, 46.4, 52.6, $123.2\left(J_{\mathrm{CF}}=272.6 \mathrm{~Hz}\right), 124.2\left(J_{\mathrm{CF}}=3.8 \mathrm{~Hz}\right), 129.4\left(J_{\mathrm{CF}}=\right.$ $3.4 \mathrm{~Hz}), 130.0,130.8,131.5\left(J_{\mathrm{CF}}=33.3 \mathrm{~Hz}\right), 140.9,159.5$, 168.3; MS (APCI) $\mathrm{m} / \mathrm{z} 495.2\left(\mathrm{M}^{+}, 100 \%\right)$; Anal. calcd. for $\mathrm{C}_{18} \mathrm{H}_{25} \mathrm{~N}_{6} \mathrm{O}_{5} \mathrm{SF}_{3} \cdot 0.5 \mathrm{H}_{2} \mathrm{O}$ : C, 42.94; H, 5.40; N, 16.69; S, 6.37\%. Found: C, 42.78; H, 4.97; N, 16.23, S, 6.77\%.

3-Trifluoromethyl-benzenesulfonic acid \{4-nitroguanidino1(S)-[4-(benzyloxycarbonyl)-piperazin-1-yl-carbonyl]butyl $\}$ amide (5b). White amorphous solid; $R_{\mathrm{f}}=0.2\left(\mathrm{SiO}_{2}\right.$, EtOAc, UV); IR $v_{\max }(\mathrm{KBr}) 3234,2927,2863,1699,1636,1429,1327,1231$, $1166,1132 \mathrm{~cm}^{-1} ; \delta_{\mathrm{H}}\left(300 \mathrm{MHz}, \mathrm{CDCl}_{3}, \mathrm{Me}_{4} \mathrm{Si}\right) 1.60(2 \mathrm{H}, \mathrm{m})$, $1.78(2 \mathrm{H}, \mathrm{m}), 3.0-3.6(10 \mathrm{H}, \mathrm{m}), 4.18(1 \mathrm{H}, \mathrm{m}), 5.08(2 \mathrm{H}, \mathrm{s}), 6.77$ $(1 \mathrm{H}$, br s), $7.30(5 \mathrm{H}, \mathrm{m}), 7.40(2 \mathrm{H}, \mathrm{m}), 7.60(1 \mathrm{H}, \mathrm{t}, J=7.6 \mathrm{~Hz})$, $7.78(1 \mathrm{H}, \mathrm{d}, J=7.6 \mathrm{~Hz}), 8.02(1 \mathrm{H}, \mathrm{d}, J=7.6 \mathrm{~Hz}), 8.04(1 \mathrm{H}$, s), $8.60\left(1 \mathrm{H}\right.$, br s); $\delta_{\mathrm{C}}\left(50 \mathrm{MHz}, \mathrm{CDCl}_{3}, \mathrm{Me}_{4} \mathrm{Si}\right) 24.2,29.9,40.4$, $41.8,43.0,43.5,44.9,52.6,67.5,123.1\left(J_{\mathrm{CF}}=273 \mathrm{~Hz}\right), 124.0$, $127.7,127.8,128.1,128.4,129.2,129.9,130.6,131.4\left(J_{\mathrm{CF}}=\right.$ $33 \mathrm{~Hz}$ ), 136.0, 140.7, 154.8, 158.9, 168.8; MS (APCI) $m / z 630.1$ $\left(\mathrm{M}^{+}, 100 \%\right)$; Anal. calcd. for $\mathrm{C}_{25} \mathrm{H}_{30} \mathrm{~N}_{7} \mathrm{O}_{7} \mathrm{SF}_{3}$ : C, 47.69; $\mathrm{H}, 4.80$; $\mathrm{N}, 15.57 ; \mathrm{S}, 5.09 \%$. Found: C, 47.52; H, 4.85; N, 15.13; S, 5.13\%.

(3- $\{$ 4-[(S)-5-Nitroguanidino-2-(3-trifluoromethyl-benzenesulfonylamino)pentanoyl]piperazin-1-yl $\}$ propyl)carbamic acid 4nitrobenzyl ester (5c). Beige amorphous solid; $R_{\mathrm{f}}=0.5\left(\mathrm{SiO}_{2}\right.$, $\mathrm{CH}_{2} \mathrm{Cl}_{2}$-isopropanol 9: 1, UV); IR $v_{\text {max }}\left(\mathrm{CH}_{2} \mathrm{Cl}_{2}\right.$ liquid film on $\mathrm{NaCl}) 3308,2946,1716,1635,1608,1522,1436,1348,1327$, $1263,1166 \mathrm{~cm}^{-1} ; \delta_{\mathrm{H}}\left(300 \mathrm{MHz}, \mathrm{CDCl}_{3}, \mathrm{Me}_{4} \mathrm{Si}\right) 1.66(2 \mathrm{H}, \mathrm{m})$, $1.80(2 \mathrm{H}, \mathrm{m}), 1.97-2.06(2 \mathrm{H}, \mathrm{m}), 2.30-2.38,(2 \mathrm{H}, \mathrm{m}), 2.34(4 \mathrm{H}$, m), $3.26(5 \mathrm{H}, \mathrm{m}), 3.34(3 \mathrm{H}, \mathrm{m}), 4.15(1 \mathrm{H}, \mathrm{m}), 5.18(2 \mathrm{H}, \mathrm{s}), 5.66$ $(1 \mathrm{H}, \mathrm{t}), 6.62(1 \mathrm{H}, \mathrm{br} \mathrm{s}), 7.51(2 \mathrm{H}, \mathrm{d}, J=8.7 \mathrm{~Hz}), 7.66(1 \mathrm{H}, \mathrm{t}$, $J=8.1 \mathrm{~Hz}), 7.81(1 \mathrm{H}, \mathrm{d}, J=8.1 \mathrm{~Hz}), 8.04(1 \mathrm{H}, \mathrm{d}, J=8.1 \mathrm{~Hz})$, $8.06(1 \mathrm{H}, \mathrm{s}), 8.21(2 \mathrm{H}, \mathrm{d}, J=8.7 \mathrm{~Hz}) ; \delta_{\mathrm{C}}\left(75 \mathrm{MHz}, \mathrm{CDCl}_{3}, \mathrm{Me}_{4} \mathrm{Si}\right)$ $25.3,26.0,29.8,40.0,42.0,45.1,52.2,52.7,52.8,55.9,64.8$, $123.0\left(J_{\mathrm{CF}}=273 \mathrm{~Hz}\right), 123.5,124.0\left(J_{\mathrm{CF}}=4 \mathrm{~Hz}\right), 126.4\left(J_{\mathrm{CF}}=\right.$ $4 \mathrm{~Hz}), 127.9,129.8,130.7,131.1\left(J_{\mathrm{CF}}=32 \mathrm{~Hz}\right), 144.4,146.1$, 147.2, 155.8, 159.4, 168.2; MS (ESI) $\mathrm{m} / \mathrm{z} 732.2\left(\mathrm{M}^{+}, 100 \%\right)$; Anal. Calcd. for $\mathrm{C}_{28} \mathrm{H}_{36} \mathrm{~N}_{9} \mathrm{O}_{9} \mathrm{SF}_{3}$ : C, 45.96; H, 4.96; N, $17.23 \%$. Found: C, 46.06; H, 5.09.

(12-\{4-I(S)-5-Nitroguanidino-2-(3-trifluoromethyl-benzenesulfonylamino)pentanoyl|piperazin-1-yl $\}$ dodecyl)carbamic acid 4-nitrobenzyl ester (5d). Orange amorphous solid; $R_{\mathrm{f}}=0.4$ $\left(\mathrm{SiO}_{2}, \mathrm{CH}_{2} \mathrm{Cl}_{2}\right.$-isopropanol 9 : 1, UV); IR $v_{\max }\left(\mathrm{CH}_{2} \mathrm{Cl}_{2}\right.$ liquid film on $\mathrm{NaCl}$ ) 3314, 2928, 2854, 1707, 1632, 1523, 1431, 1347, $1327,1263,1166,1134 \mathrm{~cm}^{-1} ; \delta_{\mathrm{H}}\left(300 \mathrm{MHz}, \mathrm{CDCl}_{3}, \mathrm{Me}_{4} \mathrm{Si}\right) 1.24$ $(16 \mathrm{H}, \mathrm{m}), 1.39(2 \mathrm{H}, \mathrm{m}), 1.50(2 \mathrm{H}, \mathrm{m}), 1.62(2 \mathrm{H}, \mathrm{m}), 1.85(2 \mathrm{H}$, $\mathrm{m}), 1.98(2 \mathrm{H}, \mathrm{m}), 2.22(2 \mathrm{H}, \mathrm{m}), 2.35(2 \mathrm{H}, \mathrm{m}), 3.19(2 \mathrm{H}, \mathrm{q}, J=$ $6.6 \mathrm{~Hz}), 3.25(2 \mathrm{H}, \mathrm{m}), 3.36(4 \mathrm{H}, \mathrm{m}), 4.10(1 \mathrm{H}, \mathrm{m}), 4.91(1 \mathrm{H}, \mathrm{m})$, $5.18(2 \mathrm{H}, \mathrm{s}), 6.60(1 \mathrm{H}, \mathrm{m}), 7.50(2 \mathrm{H}, \mathrm{d}, J=8.7 \mathrm{~Hz}), 7.68(1 \mathrm{H}, \mathrm{t}$, $J=7.5 \mathrm{~Hz}), 7.81(1 \mathrm{H}, \mathrm{d}, J=7.5 \mathrm{~Hz}), 8.04(1 \mathrm{H}, \mathrm{d}, J=8.7 \mathrm{~Hz})$, $8.07(1 \mathrm{H}, \mathrm{s}), 8.20(2 \mathrm{H}, \mathrm{d}, J=8.4 \mathrm{~Hz}) ; \delta_{\mathrm{C}}\left(50 \mathrm{MHz}, \mathrm{CDCl}_{3}\right.$, $\left.\mathrm{Me}_{4} \mathrm{Si}\right)$ 24.7, 25.6, 26.8, 27.0, 27.6, 29.5, 29.8, 30.1, 40.4, 41.4, $42.5,45.5,52.5,52.6,53.1,58.4,65.2,123.2\left(J_{\mathrm{CF}}=273 \mathrm{~Hz}\right)$, $123.8,124.4\left(J_{\mathrm{CF}}=4 \mathrm{~Hz}\right), 128.2,129.7\left(J_{\mathrm{CF}}=4 \mathrm{~Hz}\right), 130.2$, $130.9,131.6\left(J_{\mathrm{CF}}=34 \mathrm{~Hz}\right), 140.5,144.4,146.6,147.6,155.9$, 159.3, 168.0; MS (APCI) $m / z$ 858.5 (M+ $100 \%$ ); HRMS (ESI): 880.3596 (calcd for $\mathrm{C}_{37} \mathrm{H}_{54} \mathrm{~N}_{9} \mathrm{O}_{9} \mathrm{SF}_{3} \mathrm{Na}$ : 880.3615).

4.1.4 General procedure for the preparation of 3-(trifluoromethyl)benzenesulfonic acid [4-guanidino-1 $(S)$-(azacyclohexan1-ylcarbonyl)butyl|amide (1). Product 5 (1.01 mmol, 1 equiv) was dissolved in a $3: 1$ mixture of $\mathrm{EtOH}-\mathrm{AcOH}(10 \mathrm{~mL})$. The flask was purged with nitrogen and the catalyst Pd/C 10\% ( $0.091 \mathrm{~g}, 0.086 \mathrm{mmol}, 0.085$ equiv) was added. The reaction mixture was then stirred at $50{ }^{\circ} \mathrm{C}$ for $12 \mathrm{~h}$ under hydrogen atmosphere. The catalyst was filtered off and the solution was concentrated under reduced pressure. The solid residue was crystallized from a solution of $\mathrm{H}_{2} \mathrm{O}-\mathrm{MeOH} 1: 1$ and washed 
with $\mathrm{Et}_{2} \mathrm{O}$. The solvent was evaporated and the product was isolated as acetate salt (about $90 \%$ yield).

3-Trifluoromethyl-benzenesulfonic acid [4-guanidino-1(S)(piperidin-1-yl-carbonyl)butyl]amide (1a). White amorphous solid; IR $v_{\max }(\mathrm{KBr}) 3333,3200,2944,2853,1639,1325,1163$, $1122 \mathrm{~cm}^{-1} ; \delta_{\mathrm{H}}\left(300 \mathrm{MHz}, \mathrm{CD}_{3} \mathrm{OD}\right) 1.23(2 \mathrm{H}, \mathrm{m}), 1.43(4 \mathrm{H}, \mathrm{m})$, $1.61(4 \mathrm{H}, \mathrm{m}), 3.01-3.21(6 \mathrm{H}, \mathrm{m}), 4.18(1 \mathrm{H}, \mathrm{m}), 7.67(1 \mathrm{H}, \mathrm{t}, J=$ $8.1 \mathrm{~Hz}), 7.83(1 \mathrm{H}, \mathrm{d}, J=7.8 \mathrm{~Hz}), 7.99(1 \mathrm{H}, \mathrm{d}), 8.00(1 \mathrm{H}, \mathrm{s}) ; \delta_{\mathrm{C}}$ (50 MHz, $\left.\mathrm{CD}_{3} \mathrm{OD}\right) 25.1,25.9,26.4,27.5,31.2,41.9,44.3,47.5$, $53.7,124.7\left(J_{\mathrm{CF}}=276.6 \mathrm{~Hz}\right), 125.3\left(J_{\mathrm{CF}}=3.8 \mathrm{~Hz}\right), 130.5\left(J_{\mathrm{CF}}=\right.$ $3.6 \mathrm{~Hz}), 131.3,132.1,132.4\left(J_{\mathrm{CF}}=33.1 \mathrm{~Hz}\right), 143.1,158.8,170.1$; MS (APCI) $m / z 450.3\left(\mathrm{M}^{+}, 100 \%\right)$; HRMS (ESI) $\mathrm{m} / \mathrm{z}: 450.1762$ (calcd for $\mathrm{C}_{18} \mathrm{H}_{27} \mathrm{~N}_{5} \mathrm{O}_{3} \mathrm{SF}_{3}$ : 450.1787).

3-Trifluoromethyl-benzenesulfonic acid [4-guanidino-1(S)(piperazin-1-ylcarbonyl)butyl|amide (1b). White amorphous solid; IR $v_{\max }(\mathrm{KBr}) 3500-3000,1657,1549,1423,1322$, $1163 \mathrm{~cm}^{-1} ; \delta_{\mathrm{H}}\left(300 \mathrm{MHz}, \mathrm{CD}_{3} \mathrm{OD}\right) 1.37(2 \mathrm{H}, \mathrm{m}), 1.44(2 \mathrm{H}$, m), $2.66(1 \mathrm{H}, \mathrm{m}), 2.79(2 \mathrm{H}, \mathrm{m}), 2.92(3 \mathrm{H}, \mathrm{m}), 3.26(2 \mathrm{H}, \mathrm{m}), 3.48$ $(2 \mathrm{H}, \mathrm{m}), 4.10(1 \mathrm{H}, \mathrm{m}), 7.56(1 \mathrm{H}, \mathrm{t}, J=7.5 \mathrm{~Hz}), 7.69(1 \mathrm{H}, \mathrm{d}, J=$ $7.5 \mathrm{~Hz}), 7.88(1 \mathrm{H}, \mathrm{d}), 7.89(1 \mathrm{H}, \mathrm{s}) ; \delta_{\mathrm{C}}\left(50 \mathrm{MHz}, \mathrm{CD}_{3} \mathrm{OD}\right)$ $25.1,30.9,40.9,41.8,44.5,44.9,45.1,53.6,125.2,130.5$, 131.6, 132.0, 132.8, 143.5, 158.8, $171.0 \quad\left(\mathrm{CF}_{3}\right.$ not visible); $\mathrm{MS}$ (APCI) $\mathrm{m} / \mathrm{z} 451.3\left(\mathrm{M}^{+}, 100 \%\right)$; Anal. calcd. for $\mathrm{C}_{17} \mathrm{H}_{25} \mathrm{~N}_{6} \mathrm{O}_{3} \mathrm{SF}_{3} \cdot \mathrm{CH}_{3} \mathrm{COOH} \cdot 4 \mathrm{H}_{2} \mathrm{O}: \mathrm{C}, 39.18 ; \mathrm{H}, 6.40 ; \mathrm{N}, 14.4 \%$. Found: C, 38.85; H, 6.12; N, 13.97\%.

$N$-\{(S)-1-[4-(3-Aminopropyl)piperazine-1-carbonyl]-4-guanidino-butyl $\}$-3-trifluoromethyl-benzenesulfonamide (1c). Beige amorphous solid; IR $v_{\max }\left(\mathrm{CH}_{2} \mathrm{Cl}_{2}\right.$ liquid film on $\left.\mathrm{NaCl}\right) 3395$, $1636,1558,1412,1328,1165 \mathrm{~cm}^{-1} ; \delta_{\mathrm{H}}\left(500 \mathrm{MHz}, \mathrm{CD}_{3} \mathrm{OD}\right) 1.61$ $(6 \mathrm{H}, \mathrm{m}), 2.16(2 \mathrm{H}, \mathrm{m}), 2.22(1 \mathrm{H}, \mathrm{m}), 2.29(3 \mathrm{H}, \mathrm{m}), 2.63(2 \mathrm{H}, \mathrm{t}, J$ $=7.4 \mathrm{~Hz}), 3.13(2 \mathrm{H}, \mathrm{m}), 3.27-3.61(4 \mathrm{H}, \mathrm{m}), 4.00(1 \mathrm{H}, \mathrm{m}), 7.60$ $(1 \mathrm{H}, \mathrm{t}, J=8.1 \mathrm{~Hz}), 7.69(1 \mathrm{H}, \mathrm{d}, J=8.1 \mathrm{~Hz}), 8.00(1 \mathrm{H}, \mathrm{d}, J=$ $8.1 \mathrm{~Hz}), 8.04(1 \mathrm{H}, \mathrm{s}) ; \delta_{\mathrm{C}}\left(125 \mathrm{MHz}, \mathrm{CDCl}_{3}\right) 26.9,30.5,32.9$, $41.0,42.2,42.7,46.2,53.8,54.3,57.1,58.4,124.5\left(J_{\mathrm{CF}}=270 \mathrm{~Hz}\right)$, $125.1\left(J_{\mathrm{CF}}=4 \mathrm{~Hz}\right), 130.0\left(J_{\mathrm{CF}}=4 \mathrm{~Hz}\right), 131.4,132.0,132.1\left(J_{\mathrm{CF}}\right.$ $=37 \mathrm{~Hz}), 149.2,158.7,170.4$; MS (ESI) $\mathrm{m} / \mathrm{z} 508.2\left(\mathrm{M}^{+}, 100 \%\right)$; Anal. calcd. for $\mathrm{C}_{20} \mathrm{H}_{32} \mathrm{~N}_{7} \mathrm{O}_{3} \mathrm{SF}_{3} \cdot 2 \mathrm{CH}_{3} \mathrm{COOH} \cdot 1.5 \mathrm{H}_{2} \mathrm{O}: \mathrm{C}, 44.03$; H, 6.62; N, 14.98\%. Found: C, 44.37; H, 6.32; N, 14.68\%.

$\mathrm{N}$-\{(S)-1-[4-(12-Aminododecyl)piperazine-1-carbonyl]-4-guanidino-butyl $\}$-3-trifluoromethyl-benzenesulfonamide (1d). Orange amorphous solid; IR $v_{\max }(\mathrm{KBr}) 3500-2800,1647,1560$, $1407,1328,1280,1166,1134 \mathrm{~cm}^{-1} ; \delta_{\mathrm{H}}\left(300 \mathrm{MHz}, \mathrm{CD}_{3} \mathrm{OD}\right) 1.24$ $(16 \mathrm{H}, \mathrm{m}), 1.41(3 \mathrm{H}, \mathrm{m}), 1.58(6 \mathrm{H}, \mathrm{m}), 1.92(1 \mathrm{H}, \mathrm{m}), 2.04(1 \mathrm{H}$, $\mathrm{m}), 2.22(2 \mathrm{H}, \mathrm{t}, J=7.5 \mathrm{~Hz}), 2.37(4 \mathrm{H}, \mathrm{m}), 2.82(2 \mathrm{H}, \mathrm{t}, J=7.5$ $\mathrm{Hz}), 3.14(3 \mathrm{H}, \mathrm{m}), 3.34(2 \mathrm{H}, \mathrm{m}), 4.23(1 \mathrm{H}, \mathrm{m}), 7.68(1 \mathrm{H}, \mathrm{t}, J=$ $7.5 \mathrm{~Hz}), 7.81(1 \mathrm{H}, \mathrm{d}, J=7.5 \mathrm{~Hz}), 8.02(1 \mathrm{H}, \mathrm{d}, J=7.5 \mathrm{~Hz}), 8.05$ $(1 \mathrm{H}, \mathrm{s}) ; \delta_{\mathrm{C}}\left(50 \mathrm{MHz}, \mathrm{CD}_{3} \mathrm{OD}\right) 26.0,27.6,28.6,28.8,30.4,30.7$, $30.8,31.2,40.8,41.8,42.8,46.3,53.7,54.3,59.5,59.7,125.1\left(J_{\mathrm{CF}}\right.$ $=260 \mathrm{~Hz}), 125.2\left(J_{\mathrm{CF}}=4 \mathrm{~Hz}\right), 130.5\left(J_{\mathrm{CF}}=4 \mathrm{~Hz}\right), 131.6,131.8$ $\left(J_{\mathrm{CF}}=32 \mathrm{~Hz}\right), 132.3,143.4,158.9,170.5$; MS (ESI) $\mathrm{m} / z$ 634.4 $\left(\mathrm{M}^{+}, 100 \%\right)$; Anal. calcd. for $\mathrm{C}_{29} \mathrm{H}_{50} \mathrm{~N}_{7} \mathrm{O}_{3} \mathrm{SF}_{3} \cdot 3 \mathrm{CH}_{3} \mathrm{COOH}$ : C, 51.65; H, 7.68; N, 11.21\%. Found: C, 52.17; H, 7.76; N, 12.05\%.

\subsubsection{Preparation of propyl spacer arm moiety.}

(3-Bromopropyl)-carbamic acid 4-nitrobenzyl ester (6). 3Bromopropyl amine ( $2 \mathrm{~g}, 9 \mathrm{mmol}, 1$ equiv) was dissolved in water $(20 \mathrm{~mL}), \mathrm{THF}(20 \mathrm{~mL})$ and $\mathrm{NaOH} 1 \mathrm{~N}(9 \mathrm{~mL}, 9 \mathrm{mmol}, 1$ equiv). 4-Nitrobenzyl chloroformate ( $1.97 \mathrm{~g}, 9 \mathrm{mmol}, 1$ equiv) dissolved in cold THF $(5 \mathrm{~mL})$ was added dropwise to the reaction mixture at $0-5{ }^{\circ} \mathrm{C}$, simultaneously with $\mathrm{NaOH} 1 \mathrm{~N}(10 \mathrm{~mL}, 10 \mathrm{mmol}$, 1.1 equiv). The solution was then allowed to warm up at room temperature and stirred for $2 \mathrm{~h}$, checking the $\mathrm{pH}$ to be above 10. The solvent was then removed by evaporation at reduced pressure, the residue was dissolved in EtOAc and washed twice with brine. The aqueous phases were extracted once with fresh EtOAc. The organic phases were combined and dried over $\mathrm{MgSO}_{4}$ and evaporated at reduced pressure to give pure compound $6(2.85 \mathrm{~g})$ as white solid $(98 \%$ yield $) . \mathrm{Mp}=71.9-72.3{ }^{\circ} \mathrm{C}$;
$R_{\mathrm{f}}=0.5\left(\mathrm{SiO}_{2}\right.$, cyclohexane-EtOAc $\left.5: 4, \mathrm{UV}\right) ; \mathrm{IR} v_{\max }(\mathrm{KBr})$ $3417,3339,2938,2848,1705,1607,1521,1347,1245,859 \mathrm{~cm}^{-1}$; $\delta_{\mathrm{H}}\left(300 \mathrm{MHz}, \mathrm{CDCl}_{3}, \mathrm{Me}_{4} \mathrm{Si}\right) 2.1(2 \mathrm{H}$, quint, $J=6.4 \mathrm{~Hz})$, $3.37(2 \mathrm{H}, \mathrm{t}, J=6.4 \mathrm{~Hz}), 3.46(2 \mathrm{H}, \mathrm{t}, J=6.4 \mathrm{~Hz}), 5.07(1 \mathrm{H}, \mathrm{s})$, $5.20(2 \mathrm{H}, \mathrm{s}), 7.51(2 \mathrm{H}, \mathrm{d}, J=8.5 \mathrm{~Hz}), 8.22(2 \mathrm{H}, \mathrm{d}, J=8.5 \mathrm{~Hz})$; $\delta_{\mathrm{C}}\left(50 \mathrm{MHz}, \mathrm{CDCl}_{3}, \mathrm{Me}_{4} \mathrm{Si}\right) 30.5,32.3,39.5,65.1,123.6,128.0$, 143.8, 147.6, 155.7; MS (APCI) $m / z 318.9\left(\mathrm{M}^{81} \mathrm{Br}^{+}, 80 \%\right), 316.9$ $\left(\mathrm{M}^{79} \mathrm{Br}^{+}, 80 \%\right.$ ); Anal. calcd. for $\mathrm{C}_{11} \mathrm{H}_{13} \mathrm{~N}_{2} \mathrm{O}_{4} \mathrm{Br}$ : C, 41.66; H, 4.13; N, $8.83 \%$. Found: C, 41.80; H, 4.13; N, 8.81\%.

4-[3-(4-Nitrobenzyloxycarbonylamino) propyl]piperazine-1carboxylic acid tert-butyl ester (7). Boc-piperazine (1.372 g, $7.22 \mathrm{mmol}, 1$ equiv) and compound 6 (2.517 g, $7.94 \mathrm{mmol}$, 1.1 equiv.) were dissolved in dry $\mathrm{CH}_{2} \mathrm{Cl}_{2}(40 \mathrm{~mL})$ and DIPEA (4 mL, $20.4 \mathrm{mmol}, 3$ equiv). The mixture was heated at reflux for $2 \mathrm{~h}$. The solvent was then evaporated under reduced pressure and the gel obtained was extracted with EtOAc. The organic layer was then washed with brine, dried over $\mathrm{MgSO}_{4}$ and evaporated under reduced pressure. The residue was purified by column chromatography to obtain pure compound 7 (2.72 g), as a yellow gel ( $84 \%$ yield). $R_{\mathrm{f}}=0.3\left(\mathrm{SiO}_{2}\right.$, EtOAc-acetone 2 : 1, UV); IR $v_{\max }\left(\mathrm{CH}_{2} \mathrm{Cl}_{2}\right.$ liquid film on $\left.\mathrm{NaCl}\right) 2947,1719,1685$, $1523,1349,1241 \mathrm{~cm}^{-1} ; \delta_{\mathrm{H}}\left(300 \mathrm{MHz}, \mathrm{CDCl}_{3}, \mathrm{Me}_{4} \mathrm{Si}\right) 1.47(9 \mathrm{H}$, s), $1.72(2 \mathrm{H}$, quint, $J=6.5 \mathrm{~Hz}), 2.40(4 \mathrm{H}, \mathrm{t}, J=4.8 \mathrm{~Hz}), 2.47$ $(2 \mathrm{H}, \mathrm{m}), 3.32(2 \mathrm{H}, \mathrm{m}), 3.44(4 \mathrm{H}, \mathrm{t}, J=4.8 \mathrm{~Hz}), 5.20(2 \mathrm{H}, \mathrm{s})$, $6.09(1 \mathrm{H}, \mathrm{t}), 7.52(2 \mathrm{H}, \mathrm{d}, J=8.8 \mathrm{~Hz}), 8.22(2 \mathrm{H}, \mathrm{d}, J=8.8 \mathrm{~Hz})$; $\delta_{\mathrm{C}}\left(50 \mathrm{MHz}, \mathrm{CDCl}_{3}, \mathrm{Me}_{4} \mathrm{Si}\right) 25.7,28.4,40.6,43.6,52.9,56.8$, $64.8,79.7,123.5,127.9,144.2,147.3,154.5,155.7$; MS (APCI) $m / z 423.2\left(\mathrm{M}^{+}, 100 \%\right)$; Anal. calcd. for $\mathrm{C}_{20} \mathrm{H}_{30} \mathrm{~N}_{4} \mathrm{O}_{6} \cdot \mathrm{H}_{2} \mathrm{O}$ : C, 54.53 ; H, 7.32; N, $12.72 \%$. Found: C, 54.57; H, 7.36; N, 12.65\%.

(3-Piperazin-1-yl-propyl)carbamic acid 4-nitrobenzyl ester (8). A solution of $\mathrm{HCl} 1 \mathrm{~N}$ in $\mathrm{AcOH}(56 \mathrm{~mL}, 8$ equiv) was added to product 7 (2.95 g, $7 \mathrm{mmol}, 1$ equiv) and the reaction mixture was stirred at room temperature for $2 \mathrm{~h}$. The solution was concentrated by evaporation at reduced pressure to obtain a brown gel. This residue was several times triturated and suspended in $\mathrm{Et}_{2} \mathrm{O}$ until a beige solid suspension was observed. The solvent was then evaporated to obtain product $\mathbf{8}$ as hydrochloride salt (quantitative yield). To isolate the free amine, the product was dissolved in water and the solution was brought to $\mathrm{pH} 10$ with $\mathrm{NaOH} 1 \mathrm{~N}$. The aqueous solution was then extracted 5 times with EtOAc, the organic phases were combined, dried over $\mathrm{MgSO}_{4}$ and evaporated to give compound $8(2.28 \mathrm{~g})$ as a free amine (92\% product recovery). IR $v_{\max }(\mathrm{KBr})$ $3316,3214,2944,2801,1718,1607,1521,1347,1260 \mathrm{~cm}^{-1} ; \delta_{\mathrm{H}}$ $\left(200 \mathrm{MHz}, \mathrm{CDCl}_{3}, \mathrm{Me}_{4} \mathrm{Si}\right) 1.63(2 \mathrm{H}$, quint, $J=6.4 \mathrm{~Hz}), 1.94$ $(1 \mathrm{H}, \mathrm{s}), 2.37(6 \mathrm{H}, \mathrm{m}), 2.83(4 \mathrm{H}, \mathrm{t}, J=4.9 \mathrm{~Hz}), 3.23(2 \mathrm{H}, \mathrm{q}, J=$ $6.0 \mathrm{~Hz}), 5.12(2 \mathrm{H}, \mathrm{s}), 6.36(1 \mathrm{H}, \mathrm{t}, J=6.0 \mathrm{~Hz}), 7.44(2 \mathrm{H}, \mathrm{d}$, $J=8.8 \mathrm{~Hz}), 8.14(2 \mathrm{H}, \mathrm{d}, J=8.8 \mathrm{~Hz}) ; \delta_{\mathrm{C}}\left(75 \mathrm{MHz}, \mathrm{CDCl}_{3}\right.$, $\left.\mathrm{Me}_{4} \mathrm{Si}\right) 25.9$, 41.5, 46.5, 54.7, 58.2, 65.3, 124.1, 128.4, 144.8, 147.8, 156.2; MS (APCI) $m / z 323.3\left(\mathrm{M}^{+}, 100 \%\right.$ ); Anal. calcd. for $\mathrm{C}_{15} \mathrm{H}_{22} \mathrm{~N}_{4} \mathrm{O}_{4} \cdot 1.2 \mathrm{HCl}$ : C, 49.21; H, 6.34; N, 15.31\%. Found: C, 49.50; H, 6.19; N, $14.80 \%$.

\subsubsection{Preparation of dodecyl spacer arm moiety.}

12-(4-Nitrobenzyloxycarbonylamino)dodecanoic acid (9). 12-Aminododecanoic acid $(250 \mathrm{mg}, 1.16 \mathrm{mmol}, 1$ equiv) was dissolved in THF $(3 \mathrm{~mL})$, water $(3 \mathrm{~mL})$ and $\mathrm{NaOH} 1 \mathrm{~N}(1.14 \mathrm{~mL}$, 1 equiv). 4-Nitrobenzyl chloroformate $(246 \mathrm{mg}, 1.16 \mathrm{mmol}$, 1 equiv) in THF ( $1 \mathrm{~mL})$ and $\mathrm{NaOH} 1 \mathrm{~N}$ (1.3 mL, 1.1 equiv) were added simultaneously to the reaction mixture at $0{ }^{\circ} \mathrm{C}$. The solution was stirred at $0{ }^{\circ} \mathrm{C}$ for $10 \mathrm{~min}$ and then for $2 \mathrm{~h}$ at room temperature, checking $\mathrm{pH}$ was above $10 \mathrm{HCl} 1 \mathrm{~N}$ was added to the reaction mixture to reach $\mathrm{pH} 1$, and the solution was then extracted twice with EtOAc. The organic layers were combined, washed with $\mathrm{HCl} 1 \mathrm{~N}$ and water, dried over $\mathrm{MgSO}_{4}$, and evaporated under reduced pressure to give a yellow solid that was purified by column chromatography on $\mathrm{SiO}_{2}$ to obtain pure product $9(0.345 \mathrm{~g})$ as a white solid $(75 \%$ yield $)$. $\mathrm{Mp}=107.9-108.9{ }^{\circ} \mathrm{C} ; R_{\mathrm{f}}=0.3\left(\mathrm{SiO}_{2}\right.$, EtOAc-cyclohexane 
$3: 5, \mathrm{UV})$; IR $v_{\max }\left(\mathrm{CH}_{2} \mathrm{Cl}_{2}\right.$ liquid film on $\left.\mathrm{NaCl}\right) 3367,2920,2851$, $1725,1689,1613,1527,1351,1256,1246 \mathrm{~cm}^{-1} ; \delta_{\mathrm{H}}(300 \mathrm{MHz}$, $\left.\mathrm{CDCl}_{3}, \mathrm{Me}_{4} \mathrm{Si}\right) 1.27(14 \mathrm{H}, \mathrm{m}), 1.52(2 \mathrm{H}, \mathrm{m}), 1.64(2 \mathrm{H}, \mathrm{m}), 2.36$ $(2 \mathrm{H}, \mathrm{t}, J=7.1 \mathrm{~Hz}), 3.21(2 \mathrm{H}, \mathrm{m}), 4.84(1 \mathrm{H}, \mathrm{m}), 5.20(2 \mathrm{H}, \mathrm{s})$, $7.52(2 \mathrm{H}, \mathrm{d}, J=8.6 \mathrm{~Hz}), 8.22(2 \mathrm{H}, \mathrm{d}, J=8.6 \mathrm{~Hz}) ; \delta_{\mathrm{C}}(75 \mathrm{MHz}$, $\left.\mathrm{CDCl}_{3}, \mathrm{Me}_{4} \mathrm{Si}\right)$ 24.7, 26.7, 29.0, 29.1, 29.2, 29.3, 29.4, 29.9, 33.8, 41.3, 65.1, 123.7, 128.0, 144.1, 150.2, 155.7, 178.2; MS (APCI) $m / z 395.0\left(\mathrm{M}^{+}, 100 \%\right)$; Anal. calcd. for $\mathrm{C}_{20} \mathrm{H}_{30} \mathrm{~N}_{2} \mathrm{O}_{6}: \mathrm{C}, 60.90$; H, 7.65; N, 7.10\%. Found: C, 60.55; H, 7.45; N, 6.76\%.

(12-Hydroxydodecyl) carbamic acid 4-nitrobenzyl ester (10). Compound $9(0.220 \mathrm{~g}, 0.56 \mathrm{mmol}, 1$ equiv) was dissolved in dry THF $(10 \mathrm{~mL})$ and the solution was cooled down to $0^{\circ} \mathrm{C} . \mathrm{BH}_{3} 1 \mathrm{M}$ in THF (1.11 mL, $1.11 \mathrm{mmol}, 2$ equiv) was added dropwise to the solution that was then stirred for additional $2 \mathrm{~h}$ at $0{ }^{\circ} \mathrm{C}$. The reaction mixture was quenched by dropwise addition of $\mathrm{AcOH}-$ $\mathrm{MeOH} 1: 9$. The mixture was then concentrated and the residue dissolved in EtOAc. The organic phase was washed with water, dried over $\mathrm{MgSO}_{4}$, and concentrated under reduced pressure. The residue was further purified by column chromatography on $\mathrm{SiO}_{2}$ to give pure $\mathbf{1 0}(0.193 \mathrm{~g})$ as a white solid ( $91 \%$ yield $) . \mathrm{Mp}=$ 103.7-104.7 ${ }^{\circ} \mathrm{C} ; R_{\mathrm{f}}=0.6\left(\mathrm{SiO}_{2}\right.$, EtOAc-cyclohexane $4: 5$, UV); IR $v_{\max }\left(\mathrm{CH}_{2} \mathrm{Cl}_{2}\right.$ liquid film on $\left.\mathrm{NaCl}\right) 3400,2987,2865$, $1688 \mathrm{~cm}^{-1} ; \delta_{\mathrm{H}}\left(300 \mathrm{MHz}, \mathrm{CDCl}_{3}, \mathrm{Me}_{4} \mathrm{Si}\right) 1.27(16 \mathrm{H}, \mathrm{m}), 1.55$ $(4 \mathrm{H}, \mathrm{m}), 3.21(2 \mathrm{H}, \mathrm{q}, J=6.6 \mathrm{~Hz}), 3.65(2 \mathrm{H}, \mathrm{t}, J=6.6 \mathrm{~Hz}), 4.83$ $(1 \mathrm{H}, \mathrm{m}), 5.20(2 \mathrm{H}, \mathrm{s}), 7.52(2 \mathrm{H}, \mathrm{d}, J=8.7 \mathrm{~Hz}), 8.22(2 \mathrm{H}, \mathrm{d}, J=$ $8.7 \mathrm{~Hz}) ; \delta_{\mathrm{C}}\left(75 \mathrm{MHz}, \mathrm{CDCl}_{3}, \mathrm{Me}_{4} \mathrm{Si}\right) 25.8,26.7,29.2$, 29.3, 29.4, 29.5, 29.6, 29.9, 32.8, 41.3, 63.1, 65.0, 123.7, 128.0, 144.1, 150.2, 155.7; MS (APCI) $\mathrm{m} / \mathrm{z} 381\left(\mathrm{M}^{+}, 100 \%\right)$; Anal. calcd. for $\mathrm{C}_{20} \mathrm{H}_{32} \mathrm{~N}_{2} \mathrm{O}_{5}$ : C, 63.14; H, 8.48; N, 7.36\%. Found: C, 63.76; H, $8.78 ; \mathrm{N}, 7.02 \%$.

Methanesulfonic acid 12-(4-nitrobenzyloxycarbonylamino)dodecylester (11). Compound 10 (10.24 g, $26.91 \mathrm{mmol}, 1$ equiv) was dissolved in $\mathrm{CH}_{2} \mathrm{Cl}_{2}(200 \mathrm{~mL})$. Pyridine $(4.22 \mathrm{~g}, 53.83 \mathrm{mmol}$, 2 equiv) and methanesulfonyl chloride $(4.63 \mathrm{~g}, 40.37 \mathrm{mmol}$, 1.5 equiv) were added dropwise at $0{ }^{\circ} \mathrm{C}$. The solution was stirred at $0{ }^{\circ} \mathrm{C}$ for $3 \mathrm{~h}$, and for an additional $12 \mathrm{~h}$ at room temperature. The mixture was then washed with water, and $\mathrm{HCl} 1 \mathrm{~N}$, dried over $\mathrm{MgSO}_{4}$ and concentrated at reduced pressure. The residue was purified by column chromatography on $\mathrm{SiO}_{2}$ to give pure compound $\mathbf{1 1}(9.33 \mathrm{~g})$ as a white solid (76\% yield). $\mathrm{Mp}=80.9$ $82.9{ }^{\circ} \mathrm{C} ; R_{\mathrm{f}}=0.3\left(\mathrm{SiO}_{2}, \mathrm{CH}_{2} \mathrm{Cl}_{2}-\right.$ EtOAc $99: 1$, UV); IR $v_{\max }$ $\left(\mathrm{CH}_{2} \mathrm{Cl}_{2}\right.$ liquid film on $\left.\mathrm{NaCl}\right) 3370,2921,2851,1690,1614$, $1531,1355,1264,1167 \mathrm{~cm}^{-1} ; \delta_{\mathrm{H}}\left(300 \mathrm{MHz}, \mathrm{CDCl}_{3}, \mathrm{Me}_{4} \mathrm{Si}\right) 1.27$ $(14 \mathrm{H}, \mathrm{m}), 1.37(2 \mathrm{H}, \mathrm{m}), 1.52(2 \mathrm{H}, \mathrm{m}), 1.75(2 \mathrm{H}, \mathrm{tt}, J=7.0 \mathrm{~Hz})$, $3.01(3 \mathrm{H}, \mathrm{s}), 3.21(2 \mathrm{H}, \mathrm{q}, J=6.9 \mathrm{~Hz}), 4.23(2 \mathrm{H}, \mathrm{t}, J=6.8 \mathrm{~Hz})$, $4.83(1 \mathrm{H}, \mathrm{br} \mathrm{s}), 5.20(2 \mathrm{H}, \mathrm{s}), 7.51(2 \mathrm{H}, \mathrm{d}, J=8.6 \mathrm{~Hz}), 8.22(2 \mathrm{H}$, d, $J=8.6 \mathrm{~Hz}) ; \delta_{\mathrm{C}}\left(50 \mathrm{MHz}, \mathrm{CDCl}_{3}, \mathrm{Me}_{4} \mathrm{Si}\right) 25.4,26.6,28.9$, 29.1, 29.2, 29.3, 29.4, 29.5, 29.6, 29.9, 37.3, 41.2, 64.9, 70.2, 123.7, 128.0, 144.2, 147.6, 155.8; MS (APCI) $\mathrm{m} / z$ 459.1 (M+, $100 \%$ ); Anal. calcd. for $\mathrm{C}_{21} \mathrm{H}_{34} \mathrm{~N}_{2} \mathrm{O}_{7} \mathrm{~S}: \mathrm{C}, 55.00 ; \mathrm{H}, 7.47 ; \mathrm{N}, 6.11$; S, 6.99\%. Found: C, 54.85; H, 7.40; N, 6.19; S, 6.46\%.

4-[12-(4-Nitrobenzyloxycarbonylamino)dodecyl]piperazine-1carboxylic acid tert-butyl ester (12). Compound 11 (0.100 g, $0.22 \mathrm{mmol}, 1$ equiv), $\mathrm{NaI}(0.033 \mathrm{~g}, 0.22 \mathrm{mmol}, 1$ equiv), and Boc-piperazine $(0.041 \mathrm{~g}, 0.22 \mathrm{mmol}, 1$ equiv) were dissolved in $\mathrm{CH}_{3} \mathrm{CN}(5 \mathrm{~mL})$ and water $(0.2 \mathrm{~mL})$. The reaction mixture was stirred at $80{ }^{\circ} \mathrm{C}$ for $30 \mathrm{~min}$, then ethyldiisopropylamine $\left(0.028 \mathrm{~g}, 0.22 \mathrm{mmol}, 1\right.$ equiv) was added. After $12 \mathrm{~h}$ at $80^{\circ} \mathrm{C}$ the solvent was removed by evaporation and the residue dissolved in $\mathrm{CH}_{2} \mathrm{Cl}_{2}$. The organic phase was washed with water, dried over $\mathrm{MgSO}_{4}$, and concentrated at reduced pressure. The residue was purified by column chromatography on $\mathrm{SiO}_{2}$ to give pure compound $12(0.108 \mathrm{~g})$ as a yellow solid $(90 \%$ yield $)$. $\mathrm{Mp}=$ 62.6-63.6 ${ }^{\circ} \mathrm{C} ; R_{\mathrm{f}}=0.5\left(\mathrm{SiO}_{2}, \mathrm{CH}_{2} \mathrm{Cl}_{2} /\right.$ isopropanol $\left.96: 4, \mathrm{UV}\right)$; IR $v_{\max }\left(\mathrm{CH}_{2} \mathrm{Cl}_{2}\right.$ liquid film on $\left.\mathrm{NaCl}\right) 3320,2930,2855,1696$, $1601,1523,1413,1347,1252,1163 \mathrm{~cm}^{-1} ; \delta_{\mathrm{H}}\left(300 \mathrm{MHz}, \mathrm{CDCl}_{3}\right.$, $\left.\mathrm{Me}_{4} \mathrm{Si}\right) 1.24(16 \mathrm{H}, \mathrm{m}), 1.44(13 \mathrm{H}, \mathrm{m}), 2.30(2 \mathrm{H}, \mathrm{m}), 2.34(4 \mathrm{H}$, $\mathrm{m}), 3.17(2 \mathrm{H}, \mathrm{q}, J=6.6 \mathrm{~Hz}), 3.42(4 \mathrm{H}, \mathrm{m}), 5.02(1 \mathrm{H}, \mathrm{m}), 5.17$ $(2 \mathrm{H}, \mathrm{s}), 7.49(2 \mathrm{H}, \mathrm{d}, J=8.1 \mathrm{~Hz}), 8.19(2 \mathrm{H}, \mathrm{d}, J=8.7 \mathrm{~Hz})$; $\delta_{\mathrm{C}}\left(50 \mathrm{MHz}, \mathrm{CDCl}_{3}, \mathrm{Me}_{4} \mathrm{Si}\right) 26.9,27.7,28.6,29.4,29.7,29.9$,
$30.1,41.5,43.8,53.2,58.9,65.2,79.7,123.8,128.2,144.4,147.8$, 154.9, 156.1; MS (APCI) $m / z 549.9\left(\mathrm{M}^{+}, 100 \%\right)$; Anal. calcd. for $\mathrm{C}_{29} \mathrm{H}_{48} \mathrm{~N}_{4} \mathrm{O}_{6} \cdot 0.3 \mathrm{H}_{2} \mathrm{O}$ : C, 62.84; $\mathrm{H}, 8.95 ; \mathrm{N}, 10.11 \%$; Found: $\mathrm{C}, 62.76 ; \mathrm{H}, 8.85 ; \mathrm{N}, 10.07 \%$.

(12-Piperazin-1-yl-dodecyl) carbamic acid 4-nitrobenzyl ester (13). Compound 12 (0.497 g, $0.91 \mathrm{mmol}, 1$ equiv) was dissolved in a $1: 1$ mixture of TFA- $\mathrm{CH}_{2} \mathrm{Cl}_{2}(7 \mathrm{~mL})$ and the solution was stirred at room temperature for $2 \mathrm{~h}$. The solution was concentrated under reduced pressure to give a brown gel that was triturated and suspended in $\mathrm{Et}_{2} \mathrm{O}$ until precipitation of a brown solid occurred. The solvent was evaporated and compound $\mathbf{1 3}$ $(0.510 \mathrm{~g})$ was recovered as the trifluoroacetate salt (quantitative yield). $\mathrm{Mp}=79.5-80.5^{\circ} \mathrm{C}$; IR $v_{\max }\left(\mathrm{CH}_{2} \mathrm{Cl}_{2}\right.$ liquid film on $\left.\mathrm{NaCl}\right)$ $3354,2920,2850,1690,1612,1528,1350 \mathrm{~cm}^{-1} ; \delta_{\mathrm{H}}(300 \mathrm{MHz}$, $\left.\mathrm{CDCl}_{3}, \mathrm{Me}_{4} \mathrm{Si}\right) 1.25(16 \mathrm{H}, \mathrm{m}), 1.49(4 \mathrm{H}, \mathrm{m}), 2.33(2 \mathrm{H}, \mathrm{t}, J=7.7$ $\mathrm{Hz}), 2.47(4 \mathrm{H}, \mathrm{m}), 2.96(4 \mathrm{H}, \mathrm{m}), 3.19(2 \mathrm{H}, \mathrm{q}, J=6.7 \mathrm{~Hz}), 3.99$ $(1 \mathrm{H}, \mathrm{m}), 4.93(1 \mathrm{H}, \mathrm{m}), 5.18(2 \mathrm{H}, \mathrm{s}), 7.50(2 \mathrm{H}, \mathrm{d}, J=8.4 \mathrm{~Hz})$, $8.21(2 \mathrm{H}, \mathrm{d}, J=8.7 \mathrm{~Hz}) ; \delta_{\mathrm{C}}\left(50 \mathrm{MHz}, \mathrm{CDCl}_{3}, \mathrm{Me}_{4} \mathrm{Si}\right) 25.3,26.6$, 26.9, 29.1, 29.3, 29.4, 29.6, 29.9, 30.7, 41.2, 42.6, 49.3, 57.9, 65.0, 123.6, 128.0, 144.3, 147.6, 155.9; MS (APCI) $\mathrm{m} / \mathrm{z} 449.4\left(\mathrm{M}^{+}\right.$, $100 \%$ ); HRMS (ESI) $m / z 449.3119$ (calcd. for $\mathrm{C}_{24} \mathrm{H}_{41} \mathrm{~N}_{4} \mathrm{O}_{4}=$ 449.3128)

\subsection{Polymer surface modification}

The polymer materials considered were poly(ethylene terephthalate) (PET) track-etched micro-porous membrane (Whatman S.A., thickness $12 \mu \mathrm{m}$, density $1.39 \mathrm{~g} \mathrm{~cm}^{-3}$, pore diameter $0.49 \mu \mathrm{m}$, pore density $1.45 \times 10^{6}$ pore $\mathrm{cm}^{-2}$ ) and poly(butylene terephthalate) (PBT) melt blown filtration membrane (Johns Manville, thickness $133 \mu \mathrm{m}$, mean flow pore $5 \mu \mathrm{m}$, basis weight $82 \mathrm{gsm})$. The surface chemical composition of the derivatized polymers was determined by XPS with a SSX 100/206 photoelectron spectrometer from Surface Science Instruments (USA) equipped with a monochromatized microfocus Al X-ray source (powered at $20 \mathrm{~mA}$ and $10 \mathrm{kV}$ ). The pressure in the analysis chamber was around $10^{-6} \mathrm{~Pa}$. The angle between the surface normal and the axis of the analyser lens was $55^{\circ}$. The analysed area was approximately $1.4 \mathrm{~mm}^{2}$ and the pass energy was set at $150 \mathrm{eV}$. In these conditions, the resolution determined by the full width at half maximum (FWHM) of the $\mathrm{Au} 4 \mathrm{f}_{7 / 2}$ peak was around $1.6 \mathrm{eV}$. A flood gun set at $10 \mathrm{eV}$ and a $\mathrm{Ni}$ grid placed $3 \mathrm{~mm}$ above the sample surface were used for charge stabilization. The binding energies were calculated with respect to the $\mathrm{C}-(\mathrm{C}, \mathrm{H})$ component of the $\mathrm{C} 1 \mathrm{~s}$ peak fixed at $284.8 \mathrm{eV}$. Data treatment was performed with the CasaXPS program (Casa Software Ltd, UK). Molar fractions were calculated using peak areas normalised on the basis of acquisition parameters and sensitivity factors provided by the manufacturer.

4.2.1 Activation and coupling. Native polyester membranes (14) were cut into disks of $13 \mathrm{~mm}$ of diameter. The polymer samples (10 disks) were stirred at $20{ }^{\circ} \mathrm{C}(\mathrm{PBT})$ or $60^{\circ} \mathrm{C}(\mathrm{PET})$ for $1 \mathrm{~h}$ into a mixture of acetone $(50 \mathrm{~mL})$, pyridine $(1.06 \mathrm{~mL})$ and $p$-toluenesulfonyl chloride $(2.5 \mathrm{~g})$. The samples were washed successively with acetone $(50 \mathrm{~mL}, 5 \mathrm{~min})$ and water $(50 \mathrm{~mL}, 5 \mathrm{~min})$. The resulted activated samples (15) were individually immersed in $1 \mathrm{~mL}$ of a $10^{-3} \mathrm{M}$ solution of inhibitor in a phosphate buffer (PBS, $\mathrm{pH}$ 7.2) $-\mathrm{CH}_{3} \mathrm{CN}$ mixture (1:1) and incubated for $2 \mathrm{~h}$ at $20^{\circ} \mathrm{C}$ with shaking. The samples were washed with $\mathrm{PBS}-\mathrm{CH}_{3} \mathrm{CN}(1 \mathrm{~mL}, 2 \times 10 \mathrm{~min})$, water $(1 \mathrm{~mL}$, $2 \times 5 \mathrm{~min}), 5 \times 10^{-3} \mathrm{M} \mathrm{HCl}(1 \mathrm{~mL}, 2 \times 5 \mathrm{~min})$ and water $(1 \mathrm{~mL}$, $2 \times 10 \mathrm{~min})$. The resulting inhibitor grafted membranes (16) were finally dried over filter paper and analysed by XPS within $24 \mathrm{~h}$. The blank samples were prepared in the same way but without addition of $p$-toluenesulfonyl chloride in the activation step.

4.2.2 XPS analysis. The surface molar fractions were measured by XPS analysis. The concentration of F tagged 
molecules on the surface was calculated from the F/C ratio. Considering for instance the polymer repeat unit of PET $\mathrm{CO}-\mathrm{C}_{6} \mathrm{H}_{4}-\mathrm{CO}_{2}-\mathrm{CH}_{2} \mathrm{CH}_{2}-\mathrm{O}-\left(\mathrm{C}_{10} \mathrm{H}_{8} \mathrm{O}_{4}\right)$ and the derivatized (by grafting of compound 1d) chain unit $-\mathrm{CO}-\mathrm{C}_{6} \mathrm{H}_{4}-\mathrm{CO}_{2}$ $\mathrm{CH}_{2} \mathrm{CH}_{2}-\mathbf{1 d}\left(\mathrm{C}_{39} \mathrm{H}_{57} \mathrm{~F}_{3} \mathrm{~N}_{7} \mathrm{O}_{6} \mathrm{~S}\right)$ we calculated the percentage of derivatized units as follows. For a mixture of $96.7 \%\left(\mathrm{C}_{10} \mathrm{H}_{8} \mathrm{O}_{4}\right)$ and $3.3 \%\left(\mathrm{C}_{39} \mathrm{H}_{57} \mathrm{~F}_{3} \mathrm{~N}_{7} \mathrm{O}_{6} \mathrm{~S}\right), \mathrm{F} / \mathrm{C} \times 100=9.9 \times 100 / 1095.7=$ 0.904 (experimental value 0.900 ). Similarly, the corrected F/C value of 0.005 for compound 1d on PBT gave a derivatization ratio of $1.9 \%$. We previously calculated on the basis of PET crystallographic data and simple geometrical considerations ${ }^{37}$ an average of $1.72 \times 10^{15}$ PET monomer units per $\mathrm{cm}^{2}$ of surface covering 10 atomic layers (the depth analysed by XPS) or about $2850 \mathrm{pmol} \mathrm{cm}-2$. Thus, $3.3 \%$ of derivatized surface monomer units corresponds to about $90 \mathrm{pmol} \mathrm{cm}^{-2}$ of fixed compound 1d. In the same way we calculated a surface concentration of compound $1 \mathrm{c}$ of about $10 \mathrm{pmol} \mathrm{cm}-2$ for a corrected $\mathrm{F} / \mathrm{C}$ value of 0.001 ( $0.4 \%$ derivatization). The lack of crystallographic data on the PBT membrane did not allow an analogue calculation of signal surface concentration.

\subsection{Biological assays}

4.3.1 Enzyme kinetics. Substrate H-D-phenylalanyl-Lpipecolyl-L-arginine- $p$-nitroanilide dihydrochloride (S2238) was obtained from Chromogenix. Human thrombin was obtained from Hypen BioMed. Enzyme kinetics studies were performed on a Cary 210 spectrophotometer.

The inhibition activities were measured by adapting the protocol developed by Lottemberg et al.: ${ }^{38} 100 \mu \mathrm{L}$ of the solution of substrate $\mathrm{S} 2238(0.1 \mathrm{mM}$ in water $)$ and $100 \mu \mathrm{L}$ of water solution of the tested compound $(50-200 \mu \mathrm{M}$ final concentration) were diluted in $2 \mathrm{~mL}$ of Tris-Hepes Buffer (Tris $0.01 \mathrm{M}$, Hepes $0.01 \mathrm{M}, \mathrm{NaCl} 0.5 \mathrm{M}$, PEG $60000.1 \% \mathrm{~m} / \mathrm{v}$, $\mathrm{pH}$ 7.8). Finally $10 \mu \mathrm{L}$ of water solution of thrombin $(10$ $\mathrm{NIH} \mathrm{mL}^{-1}, 75.2 \mathrm{nM}$ ) were added to start the reaction. The appearance of the substrate hydrolysis product ( $p$-nitroaniline) was measured at $405 \mathrm{~nm}$ as a function of time. Plots of $V / V_{\mathrm{i}}$ versus inhibitor concentration (ratio of hydrolysis in the absence and in the presence of inhibitors) gave the inhibition constants indicated in Table 2.

4.3.2 Clot formation. For the evaluation of material hemocompatibility we used a simple test based on the weight measurement of the blood clot formed on given substrates (polymer squares of $4 \times 4 \mathrm{~cm}$ fixed on a cylindrical glass support of $2.6 \mathrm{~cm}$ internal diameter) after blood contact and incubation. Human blood was withdrawn from a healthy volunteer, collected in citrated tubes and used within a day. For coating experiments $200 \mu \mathrm{L}$ of a $10^{-3} \mathrm{M}$ solution of the tested compound were placed on the polymer surface that was then dried overnight. After weighing the samples, $200 \mu \mathrm{L}$ of human blood were placed on the surface, $20 \mu \mathrm{L}$ of $\mathrm{CaCl}_{2}$ were added to start coagulation and the samples were incubated statically for $1.5 \mathrm{~h}$ at $37^{\circ} \mathrm{C}$ in a saturated water atmosphere and $5 \% \mathrm{CO}_{2}$. The samples were then washed with water $(3 \times 2 \mathrm{~mL})$, the clot was fixed with formaldehyde ( $2 \mathrm{~mL}$ of a $5 \%$ solution in water) and then washed with water $(2 \mathrm{~mL})$. The samples were dried in oven $\left(37^{\circ} \mathrm{C}\right)$ until constant weight. The sample weight differences gave the weight of the formed clot. Native polymer coated with heparin (Leo, 5000 I.E./U.I./mL, $200 \mu \mathrm{L}$ ) was used as anti-clotting reference sample.

\subsection{Docking study}

Molecular modelling studies were performed on a Silicon Graphics Octane2 workstation.

Gold implements a genetic algorithm allowing the proteinligand docking with full ligand and partial protein flexibility. Indeed, conformation of some amino acids (Ser, Thr and Lys) are optimized during the run. The energy function is partly based on conformational and non-bonded contact information from the CSD database. Parameters: Popsiz $=100$; $\operatorname{maxops}=100000$; niche size $=2$.

Autodock uses a hybrid method called Lamarckian Genetic Algorithm (genetic algorithm coupled with a local search) to predict the interaction of flexible ligands with rigid macromolecular targets. The scoring function includes van der Waals, coulombic electrostatic, directional hydrogen bonding, entropy of ligand binding and desolvation contributions. Parameters: Runs $=200$; Population size $=50$; Number of generations $=27000$.

Discover 3 uses the molecular mechanics to optimize the conformation of the ligand-protein complex and evaluate the interaction energy (the enthalpic contribution of the binding) which is the sum of coulombic and van der Waals terms $\left(\Delta E_{\mathrm{cb}}\right.$ and $\left.\Delta E_{\mathrm{vdw}}\right)$. The backbone is moved following force constants; side chains and water molecules move freely.

Forcefield: CVFF; Dielectric constant: $1 *$ r; Criteria convergence: $10 \mathrm{kcal} \mathrm{mol}^{-1}$ for the Steepest Descent algorithm, 0.01 for the Conjugate Gradient one.

The thrombin amino acid residues were numbered by the chymotrypsin(ogen) numbering system as suggested by Bode et al. ${ }^{19}$

\subsection{Crystallization, data collection and structure refinement}

Human $\alpha$-thrombin was obtained from Kordia Life Sciences (Leiden, The Netherlands) and its anion-binding exosite inhibitor, the hirudin peptide fragment (54-65), was obtained from Bachem (Bubendorf, Switzerland). Crystals of human $\alpha-$ thrombin were grown in the presence of hirudin and compound 1c using the hanging drop vapour diffusion technique at $293 \mathrm{~K}$. Prior to the crystallization, the protein was solubilized to approximately $10 \mathrm{mg} \mathrm{ml}^{-1}$ in $0.36 \mathrm{M} \mathrm{NaCl}, 96 \mathrm{mM} \mathrm{pH} 6.5$ citrate buffer, containing hirudin at a concentration of $3 \mathrm{mM}$. Drops were prepared by mixing $1 \mu 1$ of protein solution with $1 \mu 1$ of compound 1c at a final concentration of $2.9 \mathrm{mM}$ to $1 \mu \mathrm{l}$ of reservoir solution. The reservoir solution contained $20 \%$ PEGMME 5000, $0.36 \mathrm{M} \mathrm{NaCl}$ in $0.1 \mathrm{M}$ HEPES buffer $\mathrm{pH}$ 7.5. Compound 1c was additionally further diffused into the crystal for $72 \mathrm{~h}$ from a $44 \mathrm{mM}$ solution containing $22 \%$ PEGMME 5000 and $0.36 \mathrm{M} \mathrm{NaCl}$ to a final concentration of $16 \mathrm{mM}$.

One crystal was flash frozen in liquid nitrogen after rapid soaking in a cryoprotectant solution containing about $50 \%$ glycerol in the crystallization buffer. Data were collected at ESRF (European Synchrotron Radiation Facility, Grenoble, France) on beamline BM30a at a wavelength value of $0.9797 \AA$. All data were recorded on a MarCCD detector, and intensities were indexed and integrated using MOSFLM version 6.01. ${ }^{39}$ This single crystal, belonging to space group $C 2$ with unit cell dimensions $a=70.51 \AA, b=71.34 \AA, c=72.56 \AA$ and $\beta=$ $100.59^{\circ}$, diffracted to $1.65 \AA$ resolution. The scaling of the intensity data was accomplished with SCALA of the CCP4 program suite, ${ }^{40}$ and all corresponding statistics are given in Table 7.

The phasing procedure for solving the structure was the molecular replacement method using the AMoRe package. ${ }^{41}$ The structure of the complex human $\alpha$-thrombin/hirugen (PDB code $1 \mathrm{HTG})^{42}$ was used as the search model for the rotation and translation searches. Model building with TURBO-FRODO ${ }^{43}$ and refinement with CNS $1.1^{44}$ gave final overall crystallographic $R$ factors of $24.3 \%$ (working) and $27.2 \%$ (free), with values in the outer shell of $27.5 \%$ and $31.7 \%$, respectively, for 2333 protein atoms, 34 inhibitor atoms and 187 water molecules. The statistics of refinement are summarized in Table 7 . The inhibitor density was very clear as shown in Fig. 3A: the refined temperature factors for the inhibitor range from 15 (O15 atom) to $30 \AA^{2}$.

Co-ordinates and structure factors have been deposited in the Protein Data Bank (accession code 1W7G). Figures were prepared with MOLSCRIPT/RASTER3D. ${ }^{45}$ 
Table 7 X-Ray data collection parameters and refinement statistics

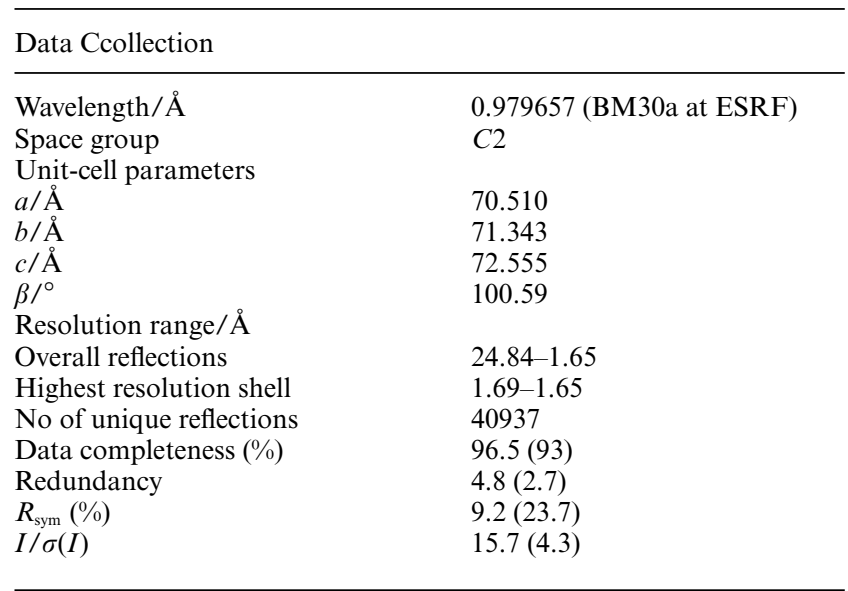

\section{Refinement}

\section{Resolution range/Å}

Completeness (working + test) $(\%)$

No. of unique reflections $(I>$

$2 \sigma(I))$

$R$ (working test) (\%)

$R_{\text {free }}$ (test set) (\%)

Protein atoms (non-H)

Heterogen atoms

Solvent atoms

$B$ values from Wilson plot $/ \AA^{2}$

Mean $B$ value (overall) $/ \AA^{2}$

Estimated coordinate errors (low

resolution cutoff of $5.0 \AA$ )

From Luzzati plot/A

From sigma $\mathrm{A} / \AA$

Deviations from ideal geometry

Bond lengths/Å

Bond angles $/^{\circ}$

Dihedral angles ${ }^{\circ}$

Improper angles $/{ }^{\circ}$

PDB entry code

$19.78-1.65(1.75-1.65)$

$95.1(90.5)$

40496 (6084)

$24.3(27.5)$

$27.2(31.7)$

2333

34

187

16.2

16.0

0.23

0.09

0.006

1.4

23.8

0.91

$1 \mathrm{~W} 7 \mathrm{G}$

\section{Acknowledgements}

This work was supported by FNRS (Fonds National de la Recherche Scientifique, IISN 4.4505.00, Belgium), the Communauté Française de Belgique (Action de Recherche Concertée no. 99/04-240) and the University of Liège (Fonds spéciaux, crédit classique 2001, R.CFRA.0460). The authors thank the "Unité de chimie des interfaces, UCL" for access to the XPS facilities. C. S. thanks Professors J. Fastrez and P. Rouxhet for helpful discussion; Dr R. Touillaux for NMR spectra interpretation; G. Nollet and S. Gharbi for providing key synthetic intermediates. J. R. thanks Dr E. Sauvage for help in the crystallographic study. J. M.-B. is senior research associate of the FNRS.

\section{References}

1 C. P. Sharma, J. Biomater. Appl., 2001, 15, 359.

2 Z. M. Yang, L. Wang, J. Yuan, J. Shen and S. C. Lin, J. Biomater. Sci., Polym. Ed., 2003, 14, 707.

3 W.-C. Lin, T.-Y. Liu and M.-C. Yang, Biomaterials, 2004, 25, 1947.

4 C. Sperling, K. Salchert, U. Streller and C. Werner, Biomaterials, 2004, 25, 5101.

5 G. W. Fussell and S. L. Cooper, Biomaterials, 2004, 25, 2971.

6 L. R. Bush, Cardiovasc. Drug Rev., 1991, 9, 247.

7 Y. Ito, L. S. Liu, R. Matsuo and Y. Imanishi, J. Biomed. Mater. Res., Part A, 1992, 26, 1065.

8 H. Noguchi, H. Iwata and Y. Ikada, J. Biomed. Mater. Res., Part A, 1998, 39, 621 .
9 M.-F. Gouzy, C. Sperling, K. Salchert, T. Pompe, U. Streller, P. Uhlmann, C. Rauwolf, F. Simon, F. Bohme, B. Voit and C. Werner, Biomaterials, 2004, 25, 3493.

10 J. Marchand-Brynaert, E. Detrait, O. Noiset, T. Boxus, Y.-J. Schneider and C. Remacle, Biomaterials, 1999, 20, 1773.

11 S. Biltresse, M. Attolini, G. Dive, A. Cordi, G. C. Tucker and J. Marchand-Brynaert, Bioorg. Med. Chem., 2004, 12, 5379.

12 J. I. Weitz and M. Crowther, Thromb. Res., 2002, 106, 275.

13 F. Thorstensson, I. Kvarnstroem, D. Musil, I. Nilsson and B. Samuelsson, J. Med. Chem., 2003, 46, 1165.

14 J.-M. Altenburger, G. Y. Lassalle, M. Matrougui, D. Galtier, J.-C. Jetha, Z. Bocskei, C. N. Berry, C. Lunven, J. Lorrain, J.-P. Herault, P. Schaeffer, S. E. O'Connor and J.-M. Herbert, Bioorg. Med. Chem., 2004, 12, 1713.

15 S. Okamoto, K. Kinjo, A. Hijikata, R. Kikumoto, Y. Tamao and K. Ohkubo, T. S., J. Med. Chem., 1980, $23,827$.

16 C. R. W. Guimaraes and R. Bicca de Alencastro, J. Med. Chem., 2002, 45, 4995

17 J. C. Danilewicz, S. M. Abel, A. D. Brown, P. V. Fish, E. Hawkeswood, S. J. Holland, K. James, A. B. McElroy, J. Overington, M. J. Powling and D. J. Rance, J. Med. Chem., 2002, 45, 2432.

18 S. Bajusz, E. Szell, D. Bagdy, E. Barabas, G. Horvath, M. Dioszegi, Z. Fittler, G. Szabo, A. Juhasz and E. Tomori, J. Med. Chem., 1990, 33, 1729.

19 W. Bode, I. Mayr, U. Baumann, R. Huber, S. R. Stone and J. Hofsteenge, EMBO J., 1989, 8, 3467.

20 K. McKeage and G. L. Plosker, Drugs, 2001, 61, 515.

21 C. W. Francis, Best Practice \& Research Clinical Haematology, 2004, 17, 139.

22 S. Biltresse, D. Descamps, C. Henneuse-Boxus and J. MarchandBrynaert, J. Polym. Sci., Part A: Polym. Chem., 2002, 40, 770

23 Y. Ito and Y. Imanishi, J. Biomater. Appl., 1992, 6, 293.

24 S. Devouge, C. Salvagnini and J. Marchand-Brynaert, Bioorg. Med. Chem. Lett., 2005, 15, 3252 .

25 R. E. Babine and S. L. Bender, Chem. Rev., 1997, 97, 1359.

26 D. K. Jones-Hertzog and W. L. Jorgensen, J. Med. Chem., 1997, 40, 1539.

27 D. W. Banner and P. Hadvary, J. Biol. Chem., 1991, 266, 20085.

28 G. M. Morris, D. S. Goodsell, R. S. Halliday, R. Huey, W. E. Hart, R. K. Belew and A. J. Olson, J. Comput. Chem., 1998, 19, 1639 .

29 G. Jones, P. Willett, R. C. Glen, A. R. Leach and R. Taylor, Gold, Astex Technology, Cambridge, UK, 2001.

30 Accelrys, Discover3, Accelrys Inc., San Diego, CA, USA, 1998.

31 M. J. Frisch, G. W. Trucks and H. B. Schlegel, Gaussian 98, Gaussian Inc., Pittsburgh, PA, USA, 2001.

32 Z. Chen, Y. Li, A. M. Mulichak, S. D. Lewis and J. A. Shafer, Arch. Biochem. Biophys., 1995, 322, 198.

33 A. Dahlgren, P.-O. Johansson, I. Kvarnstrom, D. Musil, I. Nilsson and B. Samuelsson, Bioorg. Med. Chem., 2002, 10, 1829.

34 D. Noeteberg, J. Brnalt, I. Kvarnstroem, M. Linschoten, D. Musil, J.-E. Nystroem, G. Zuccarello and B. Samuelsson, J. Med. Chem., 2000, 43, 1705.

35 J. W. Nilsson, I. Kvarnstroem, D. Musil, I. Nilsson and B. Samulesson, J. Med. Chem., 2003, 46, 3985.

36 S. Hanessian, E. Balaux, D. Musil, L.-L. Olsson and I. Nilsson, Bioorg. Med. Chem. Lett., 2000, 10, 243.

37 J. Marchand-Brynaert, Surface Functionalization of Polymer Membranes, ed. T. Smith Sorensen, Surface Chemistry and Electrochemistry of Membranes, Marcel Dekker Inc., New York-Basel, 1999, pp. 91-124.

38 R. Lottemberg, J. A. Hall, J. W. Fenton, II and C. M. Jackson, Thromb. Res., 1982, 28, 313 .

39 A. G. R. W. Leslie, Crystallogr. Comput., 1991, 5, 50.

40 Collaborative Computational Project, Acta Crystallogr., Sect. D, 1994, 50, 760 .

41 J. Navaza, Acta Crystallogr., Sect. A, 1994, 50, 157.

42 E. Skrzypczak-Jankun, V. E. Carperos, K. G. Ravichandran, A. Tulinsky, M. Westbrook and J. M. Maraganore, J. Mol. Biol., 1991, 221, 1379.

43 A. Roussel and C. Cambillau, Silicon Graphics Geometry Partner Directory, Mountain View, CA, USA, 1989.

44 A. T. Brünger, P. D. Adams, G. M. Clove, W. L. Delano, P. Gros, R. W. Grosse-Kunsteve, J.-S. Jiang, J. Kuszewski, M. Nilges and N. S. Pannu, Acta Crystallogr., Sect. D, 1998, 54, 905.

45 P. Kraulis, J. Appl. Crystallogr., 1991, 946. 